\title{
Land use policy and agricultural water management of the previous half of century in Africa
}

\author{
Mohammad Valipour
}

Received: 6 March 2014/ Accepted: 22 April 2014/Published online: 21 May 2014

(c) The Author(s) 2014. This article is published with open access at Springerlink.com

\begin{abstract}
This paper examines land use policy and agricultural water management in Africa from 1962 to 2011. For this purpose, data were gathered from Food and Agriculture Organization of the United Nations (FAO) and the World Bank Group. Using the FAO database, ten indices were selected: permanent crops to cultivated area $(\%)$, rural population to total population (\%), total economically active population in agriculture to total economically active population (\%), human development index, national rainfall index (mm/year), value added to gross domestic product by agriculture $(\%)$, irrigation water requirement (mm/year), percentage of total cultivated area drained (\%), difference between national rainfall index and irrigation water requirement ( $\mathrm{mm} / \mathrm{year})$, area equipped for irrigation to cultivated area or land use policy index $(\%)$. These indices were analyzed for all 53 countries in the study area and the land use policy index was estimated by two different formulas. The results show that value of relative error is $<20 \%$. In addition, an average index was calculated using various methods to assess countries' conditions for agricultural water management. Ability of irrigation and drainage systems was studied using other eight indices with more limited information. These indices are surface irrigation (\%), sprinkler irrigation (\%), localized irrigation (\%), spate irrigation (\%), agricultural water withdrawal $\left(10 \mathrm{~km}^{3} /\right.$ year), conservation agriculture area as percentage of cultivated area (\%), percentage of area equipped for irrigation salinized (\%), and area waterlogged by irrigation (\%). Finally, tendency of farmers to use
\end{abstract}

M. Valipour $(\square)$

Department of Water Engineering, Kermanshah Branch, Islamic Azad University, Kermanshah, Iran

e-mail: vali-pour@hotmail.com irrigation systems for cultivated crops has been presented. The results show that Africa needs governments' policy to encourage farmers to use irrigation systems and raise cropping intensity for irrigated area.

Keywords Africa - Agricultural water management . Irrigation $\cdot$ Land use policy index $\cdot$ Macroeconomic policies - Optimum decision

\section{Introduction}

Due to the limited water resources, the role of macroeconomic policies in agricultural water management is vital and undeniable. Africa has the most population growth in the world while, actual crop yield as percentage of potential yield is $40 \%$ for North Africa and it is $<30 \%$ for Sub-Saharan Africa (FAO 2012); therefore, Africa needs specific attention. Namara et al. (2010) mentioned the role of agricultural water management to reduce poverty in the world via three pathways. Those are improvement of production, enhancement of employment opportunities and stabilization of income and consumption using access to reliable water (first pathway), increasing high-value products (second pathway), and finally by its role in nutritional status, health, societal equity, and environment (third pathway). They preferred improving the management of existing systems as selected strategy in North Africa. Valipour (2012, 2013a, b, c) mentioned the status of irrigated and rainfed agriculture in the world, summarized the advantages and disadvantages of irrigation systems, and attend to update irrigation information to select optimum decision. The present paper shows that $46 \%$ of cultivated areas in the world are not suitable for rainfed agriculture because of climate changes and other 
meteorological conditions. The value of irrigation-equipped areas as share of cultivated areas was $5.8 \%$ and the value of water-managed areas as share of cultivated areas was $6.7 \%$ for Africa. In addition, Mati (2011) discussed the effects of optimizing agricultural water management for the green revolution in Africa. Hanjra et al. (2009b) and Burney et al. (2013) argued about the favourable impact of investments in agricultural water management for Sub-Saharan Africa. They claimed that poverty was significantly reduced in equipped area than in rainfed area, and concluded that investments in agricultural water management and complementary rural infrastructure and related policies were the pathways to break the poverty trap in Sub-Saharan African agriculture. Franks et al. (2008) examined developing capacity for agricultural water management in current practice and future directions. They suggested increased attention to monitoring and evaluation of capacity development, and closer links to emerging work on water governance. Khan et al. (2009) reviewed water management and crop production for food security. According to the authors, relations between water and other development-related sectors such as population, energy, food, and environment, and the interactions among them require reckoning, as they together will determine future food security and poverty reduction. Funnell (1994) discussed the intervention of government or other agencies into long-established irrigation schemes and also the possible implications of intrusion into the activities of farmers who have recently moved into irrigation in Morocco and Swaziland. He suggested that any attempt to encourage greater involvement with irrigation must be accompanied by economic measures which favour small-scale production. Wheater and Evans (2009) studied relationship between land use, water management and future flood risk. They mentioned that apart from irrigation issues, water-related implications of climate change for future land use remain relatively unexplored. To conserve usable water resources, land uses which increase evapotranspiration or rapid runoff should be discouraged, particularly in the south and east, and there is need for continuous efforts to maintain good chemical water quality in rivers and groundwater. Water resource constraints will limit opportunities to use irrigation as a counter to climate change, and will influence as to where irrigated production can be located (Weatherhead and Howden 2009). Ozan and Alsharif (2013) showed homeowners irrigated more to meet the water needs of their lawns despite the restrictions imposed on them by their local government. Characteristics of land tenure and use policy during 30 years of small irrigation system operations in Niger that have enhanced beneficiary incentives and project sustainability are summarized and a closer examination of the applicability of similar policies and practices among other systems in the region is suggested (Norman 1998). In addition, Drinkwater (1989) investigated technical development and peasant impoverishment according to land use policy in Zimbabwe's Midlands Province. Hanjra et al. (2009a) showed that investments in irrigation can contribute to poverty reduction, but the poverty reducing impacts of irrigation water are greater when human capital and rural markets are well developed. The size of landholding, access to irrigation water, onfarm land and water conservation practices, literacy of the household head, and years of education of adults are all significant determinants of household welfare, and thus potential pathways for reducing poverty. Expansion of cultivated land, particularly irrigated land, universal literacy, and an extra school year for adults all reduce poverty, but reductions in poverty are greater when irrigation is combined with universal literacy. These findings call for simultaneous investments in agricultural water, education, markets and related policy support measures for reducing poverty in smallholder agriculture in Ethiopia. Calder et al. (1995) studied the impact of land use change on water resources in sub-Saharan Africa. The developed model in this study, in conjunction with realtime rainfall data obtained from land-based gauges, radar or satellite observations, can be used for real-time water resource management applications such as the operation of barrages regulating the flow from Lake Malawi or for the issuing of flood or drought warnings. Tilman et al. (2002) studied agricultural sustainability and intensive production practices. They claimed that new incentives and policies for ensuring the sustainability of agriculture and ecosystem services would be crucial if we are to meet the demands of improving yields without compromising environmental integrity or public health. Viala (2008) assess water management in agriculture successfully using FAO database. Foley et al. (2005) reviewed global consequences of land use. They concluded that we face the challenge of managing trade-offs between immediate human needs and maintaining the capacity of the biosphere to provide goods and services in the long term. The previous researches are either about a limited area, and can not be applied to other regions, or did not consider the role of all important indices for land use policy and agricultural water management. Thus, the goal of this study is to establish a link for more important parameters in agricultural water management and to investigate about land use policy and conditions of irrigation and drainage systems as well as crops cultivated based on the available data for Africa in the previous half of century. The current work provides an opportunity for key stakeholders to identify major and effective indices of land use policy and 
agricultural water management for investment plans in Africa by an accurate analysis of 18 considerable indices as well as cropping intensity and finally estimation of the land use policy index and desirability of agricultural water management for each country that have not already been investigated by other researchers.

\section{Methodology}

Many variables are required to estimate the area equipped for irrigation to cultivated area, for cropping pattern design, microeconomic decisions, and allocation of water resources. However, all parameters could not be considered due to lack of adequate data. In this study, using AQUASTAT database (FAO 2013), ten main indices were selected to assess land use policy and agricultural water management in Africa from 1962 to 2011 and the data were checked using WBG database (WBG 2013). Then, values of relative error were determined to estimate area equipped and preferred countries (based on land use policy and agricultural water management) were introduced. In the next step, eight sub-main indices (based on less information) were evaluated and the cropping intensity was presented for the study area in the past half century.

\section{Main indices}

\section{Permanent crops to cultivated area (\%)}

This index is determined as:

$I_{1}=100 \times \frac{\text { permanent crops (ha) }}{\text { cultivated area (ha) }}$

Rural population to total population (\%)

This index is determined as follows:

$I_{2}=100 \times \frac{\text { rural population (inhabitant) }}{\text { total population (inhabitant) }}$

Total economically active population in agriculture to total economically active population (\%)

This index is determined as follows:

$I_{3}$

$=100 \times \frac{\text { total economically active population in agriculture (inhabitant) }}{\text { total economically active population (inhabitant) }}$
Human development index (HDI)

The HDI $\left(I_{4}\right)$ is a composite statistic of life expectancy, education, and income indices used to rank countries into different tiers of human development.

\section{National rainfall index (NRI) (mm/year)}

The NRI is defined as the national average of the total annual precipitation weighted by its long-term average. In fact, this index $\left(I_{5}\right)$ is a type of effective rainfall.

Value added to gross domestic product (GDP) by agriculture (\%)

Agriculture corresponds to International Standard Industrial Classification (ISIC) divisions 1-5 and includes forestry, hunting, and fishing, as well as cultivation of crops and livestock production. Value added is the net output of a sector after adding up all outputs and subtracting intermediate inputs. This index $\left(I_{6}\right)$ is calculated without making deductions for depreciation of fabricated assets or depletion and degradation of natural resources.

\section{Irrigation water requirement ( $\mathrm{mm} /$ year)}

This index shows the quantity of water exclusive of precipitation and soil moisture (i.e. quantity of irrigation water) required for normal crop production. It consists of water to ensure that the crop fulfills its full crop water requirement (i.e. irrigation consumptive water use, as well as extra water for flooding of paddy fields to facilitate land preparation and to protect the plant and to leach salt when necessary to allow for plant growth. This index $\left(\mathrm{I}_{7}\right)$ corresponds to net irrigation water requirement.

\section{Percentage of total cultivated area drained (\%)}

This index shows irrigated and non-irrigated cultivated area that is drained as percentage of the total cultivated area. This index is determined as:

$I_{8}=100 \times \frac{\text { total drained area }(\mathrm{ha})}{\text { cultivated area }(\mathrm{ha})}$

Difference between national rainfall index and irrigation water requirement ( $\mathrm{mm} /$ year)

This index shows water deficit and is determined as:

$I_{9}=$ national rainfall index $(\mathrm{mm} /$ year $)$ - irrigation water requirement $(\mathrm{mm} /$ year $)$

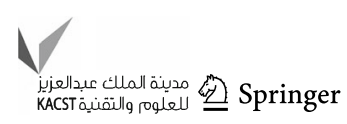


Area equipped for irrigation to cultivated area or land use policy index $(\%)$

This index is determined as:

$I_{10}=100 \times \frac{\text { area equipped for irrigation }(\mathrm{ha})}{\text { cultivated area (ha) }}$

\section{Estimation of equipped area}

The current study aims to find a link among the main indexes as:

$I_{10}=f\left(I_{1}, I_{2}, I_{3}, I_{4}, I_{5}, I_{6}, I_{7}, I_{8}, I_{9}\right)$

For this purpose, several scenarios were tested and role of each index on 10th index was identified. Finally, the function was calculated by two different methods using data of 2011 as:

$$
\begin{aligned}
& I_{10}=\frac{1}{\left.\sum_{i}^{1,2,3,6,7,8} \frac{1}{1-\left(\frac{I_{10}}{f_{c} l_{\mathrm{ni}}}\right)_{2011}}\right|^{+\sum_{i}^{5}} \frac{1}{1-\left(\frac{1}{\frac{I_{10}}{T_{c}\left(100-I_{\mathrm{ni}}\right.}}\right)_{2011}}} \\
& {\left[\sum_{i}^{1,2,3,6,7,8} \frac{I_{\mathrm{ni}}}{\left|1-\left(\frac{I_{10}}{f_{c} I_{\mathrm{ni}}}\right)_{2011}\right|}+\sum_{i}^{5,9}\left(\frac{100-I_{\mathrm{ni}}}{\left|1-\left(\frac{I_{10}}{f_{C\left(100-I_{\mathrm{ni}}\right.}}\right)_{2011}\right|}\right)\right]}
\end{aligned}
$$

$$
\begin{aligned}
& I_{10}=\frac{1}{\sum_{i}^{1,2,3,4,6,7,8} \frac{1}{\left|f_{c} I_{\mathrm{ni}}-I_{10}\right|_{2011}}+\sum_{i}^{5,9} \frac{1}{\left|f_{c}\left(100-I_{\mathrm{ni}}\right)-I_{10}\right|_{2011}}} \\
& {\left[\sum_{i}^{1,2,3,4,6,7,8} \frac{I_{\mathrm{ni}}}{\left|f_{c} I_{\mathrm{ni}}-I_{10}\right|_{2011}}+\sum_{i}^{5,9}\left(\frac{100-I_{\mathrm{ni}}}{\left|f_{c}\left(100-I_{\mathrm{ni}}\right)-I_{10}\right|_{2011}}\right)\right]}
\end{aligned}
$$

where

$I_{\mathrm{ni}}=$ Normalized index $=100 \times \frac{I_{i}}{\left(I_{i}\right)_{\max }}$

$\left(I_{i}\right)_{\max }=$ Maximum value of index among all countries

$$
\text { in Africa (53 countries) }
$$

where, $\mathrm{fc}$ is correction factor and can be updated at the end of each water year. It will be $1,0.9,0.8,0.7,0.6,0.5,0.4$, $0.3,0.2$, or 0.1 , if in 10 is $90-100,80-90,70-80,60-70$, $50-60,40-50,30-40,20-30,10-20$, or $0-10$, respectively. To determine the error of the obtained functions these formulas were applied to other years, and values of error were calculated as:
Mean error $=\frac{1}{\text { Number of tested years }}$

$$
\sum_{i=1}^{\text {Number of tested years }}\left(100 \times \frac{\left|\left(I_{10}\right)_{\text {actual }}^{i}-\left(I_{10}\right)_{\text {estimated }}\right|}{\left(I_{10}\right)_{\text {actual }}^{i}}\right)
$$

Maximum error

$$
=\underset{i=1}{\operatorname{Max}_{i=1}^{\text {Number fears }}}\left\{100 \times \frac{\left|\left(I_{10}\right)_{\text {actual }}^{i}-\left(I_{10}\right)_{\text {estimated }}\right|}{\left(I_{10}\right)_{\text {actual }}^{i}}\right\}
$$

Minimum error

$$
=\underset{i=1}{\operatorname{Min}_{\text {Number of tears }}}\left\{100 \times \frac{\left|\left(I_{10}\right)_{\text {actual }}^{i}-\left(I_{10}\right)_{\text {estimated }}\right|}{\left(I_{10}\right)_{\text {actual }}^{i}}\right\}
$$

Condition of the countries for land use policy and agricultural water management

Status of all countries was identified using two methods as:

Desirability $=I_{\text {avg1 }}$

$$
\begin{aligned}
& =\overline{\text { Number of available indexes }} \\
& {\left[I_{n 1}+I_{n 2}+I_{n 3}+I_{n 4}+I_{n 5}+I_{n 6}+\left(100-I_{n 7}\right)+I_{n 8}+I_{n 9}+I_{n 10}\right]}
\end{aligned}
$$

Desirability

$$
\begin{aligned}
& =I_{\mathrm{avg} 2}=\frac{1}{1+\sum_{i=1}^{1,2,3,4,5,6,8,9} \frac{1}{\frac{\left|f_{c} I_{\mathrm{ni}}-I_{10}\right|}{||_{c}\left(100-I_{n 7}\right)-I_{10} \mid}}} \\
& {\left[\sum_{i=1}^{1,2,3,4,5,6,8,9} \frac{I_{\mathrm{ni}}}{\left|f_{c} I_{\mathrm{ni}}-I_{10}\right|}+\frac{100-I_{n 7}}{\left|f_{c}\left(100-I_{n 7}\right)-I_{10}\right|}+I_{n 10}\right]}
\end{aligned}
$$

Then, the condition of the countries for land use policy and agricultural water management was classified in three groups: suitable status: Desirability $\geq 50 \%$, fair status: $30 \% \leq$ Desirability $<50 \%$, unsuitable status: Desirability $<30 \%$.

Sub-main indices

\section{Surface irrigation (\%)}

Surface irrigation systems are based on the principle of moving water over the land by simple gravity in order to moisten the soil. They can be subdivided into furrow, border strip and basin irrigation (including submersion 
irrigation of rice). Manual irrigation using buckets or watering cans is also included. Surface irrigation does not refer to the method of transporting the water from the source up to the field, which may be done by gravity or by pumping.

\section{Sprinkler irrigation (\%)}

A sprinkler irrigation system consists of a pipe network, through which water moves under pressure before being delivered to the crop via sprinkler nozzles. The system basically simulates rainfall in that water is applied through overhead spraying. These systems are also known as overhead irrigation systems.

\section{Localized irrigation (\%)}

Localized irrigation is a system where the water is distributed under low pressure through a piped network, in a pre-determined pattern, and applied water as a small discharge to each plant or adjacent to it. There are three main categories: drip irrigation (where drip emitters are used to apply water slowly to the soil surface), spray or micro-sprinkler irrigation (where water is sprayed to the
Fig. 1 Values of permanent crops to cultivated area $(\%)$ in 2011

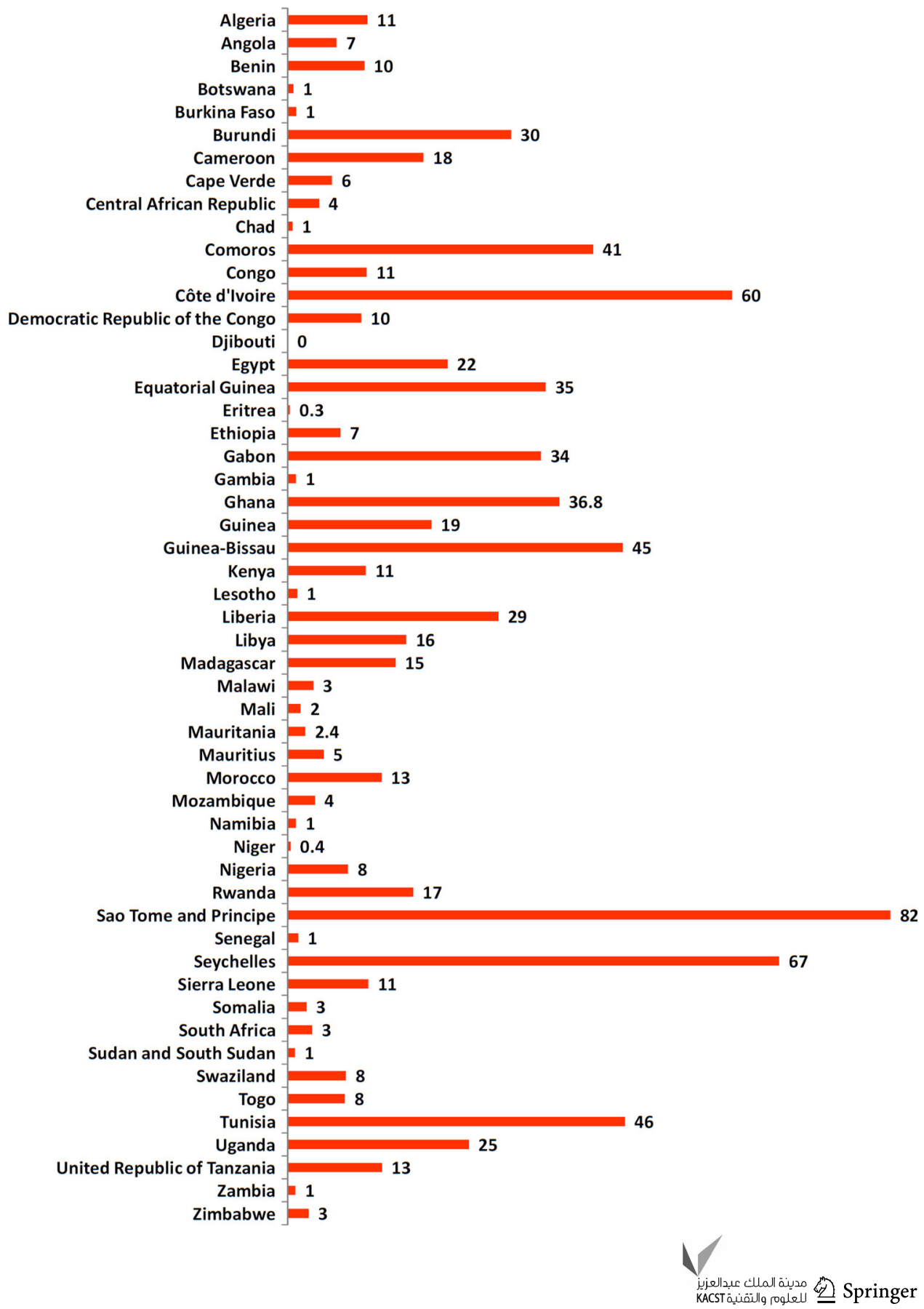


Fig. 2 Values of rural population to total population $(\%)$ in 2011

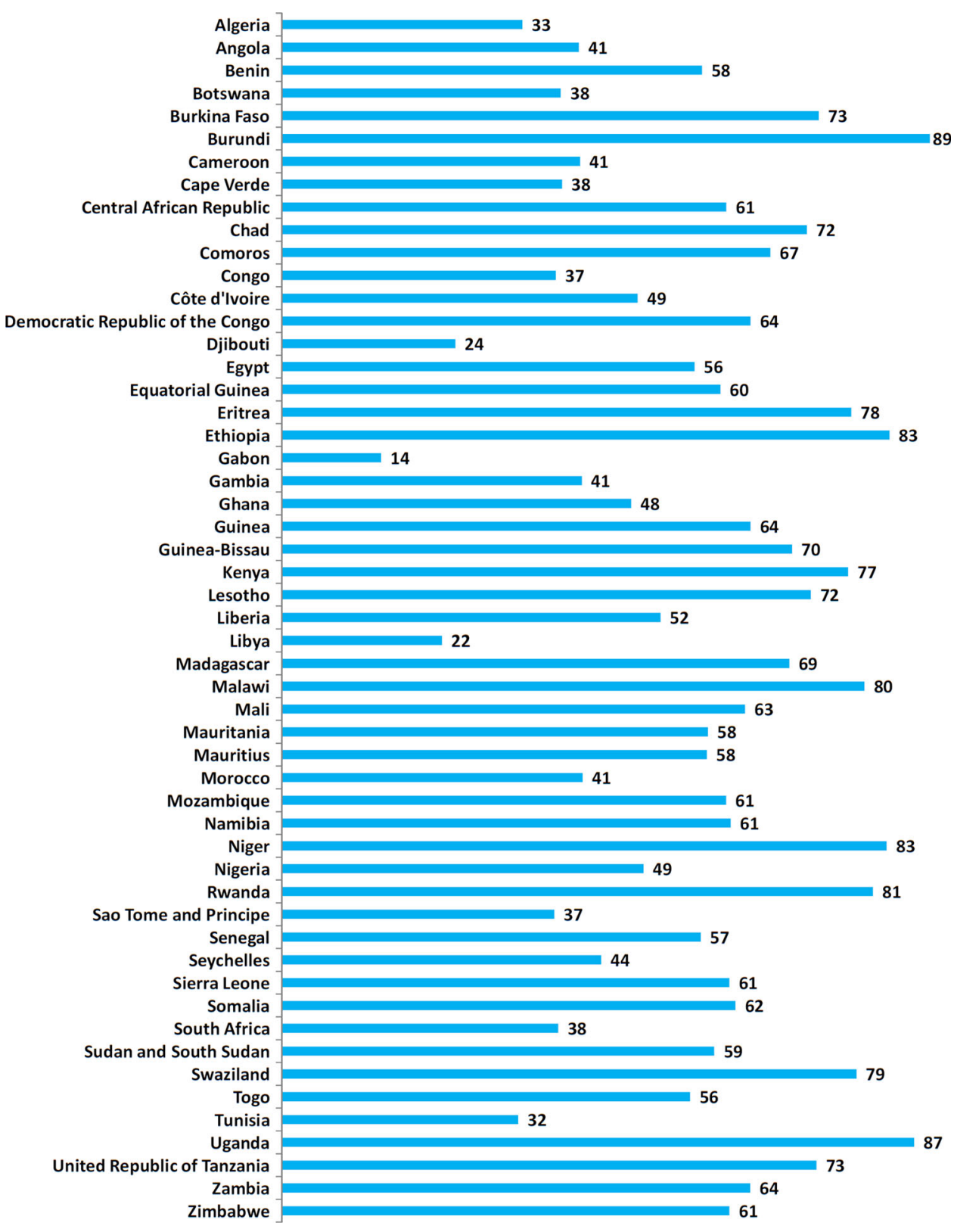

steep canals to bunded basins where cropping takes place. A dam is often built in the wadi to be able to divert the water whenever it arrives. These systems are in general characterized by a very large catchment upstream (200-5,000 ha) with a ratio of "catchment area: cultivated area" = between 100:1-10,000:1. There are two types of spate irrigation: (1) floodwater harvesting within streambeds, where turbulent channel flow is collected and spread through the wadi where the crops are planted; cross-wadi dams are constructed with stones, earth, or both, often reinforced with gabions; (2) floodwater diversion, where the floods- or spates-from the seasonal rivers are diverted into adjacent embanked fields for direct application. A vesting) is an irrigation practice that uses the floodwaters of ephemeral streams (wadi) and channels it through short 
Fig. 3 Total economically active population in agriculture to total economically active population (\%) in 2011

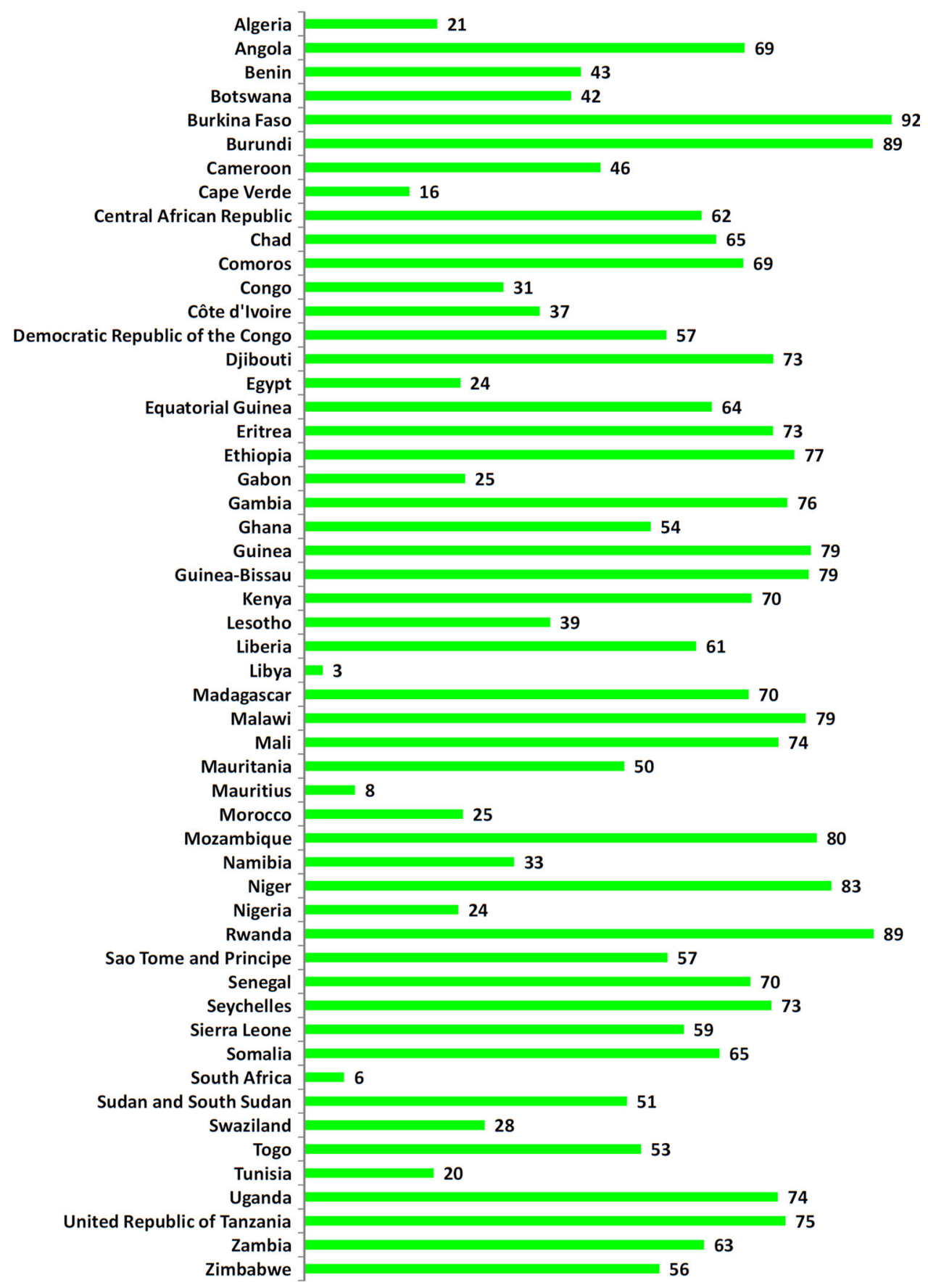

groundwater, direct use of agricultural drainage water and (treated) wastewater, and desalinated water.

Conservation agriculture area as percentage of cultivated area (\%)

Conservation agriculture (CA) is an agricultural practice, whereby the disturbed area is $<15 \mathrm{~cm}$ wide or $25 \%$ of the cropped area (whichever is lower). AQUASTAT distinguishes between 30-60\%, 61-90\% and $91 \%$ ground
This is annual quantity of self-supplied water withdrawn for irrigation, livestock and aquaculture purposes. It includes water from primary renewable and secondary freshwater resources, as well as water from over-abstraction of renewable groundwater or withdrawal of fossil

stone or concrete structure raises the water level within the wadi to be diverted to the nearby cropping areas.

\section{Agricultural water withdrawal $\left(10 \mathrm{~km}^{3} /\right.$ year $)$}


Fig. 4 Human development index (HDI) in 2011, this index is not available for Somalia

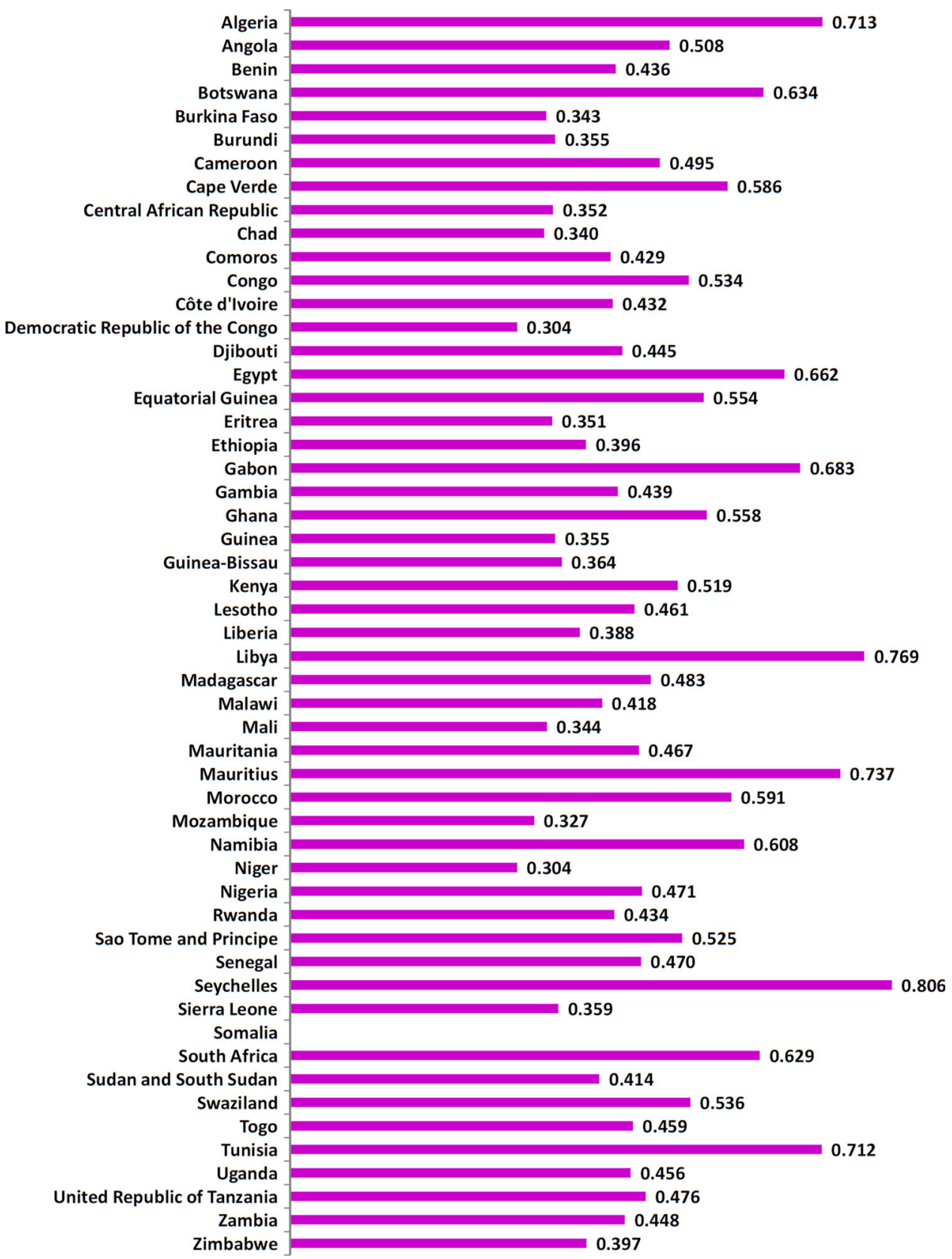

cover. Ground cover must be measured after planting time. Ground cover $<30 \%$ is not considered CA. Rotation must involve at least three different crops. Rotation is not a requirement for $\mathrm{CA}$ at this time, but AQUASTAT reports whether rotation is being carried out or not.

\section{Percentage of area equipped for irrigation salinized (\%)}

This is percentage of area equipped for irrigation that has become salinized due to mineral build-up caused by inadequate drainage.
Area waterlogged by irrigation (\%)

This is a part of the land that is waterlogged because of irrigation. Waterlogging is the state of land in which the water table is located at or near the surface resulting in a decline of crop yields. Irrigation can contribute to the raising of the level of the aquifers. The non-saturated area of soils can become too small and the soils are over-saturated with water. If recharge to groundwater is greater than natural drainage, there is a need for additional drainage to avoid waterlogging. 
Fig. 5 NRI (mm/year) in 2011, this index is not available for Cape Verde, Mauritius, Sao Tome and Principe, and Seychelles (in few cases due to lack of data, value of the index in the previous years has been reported)

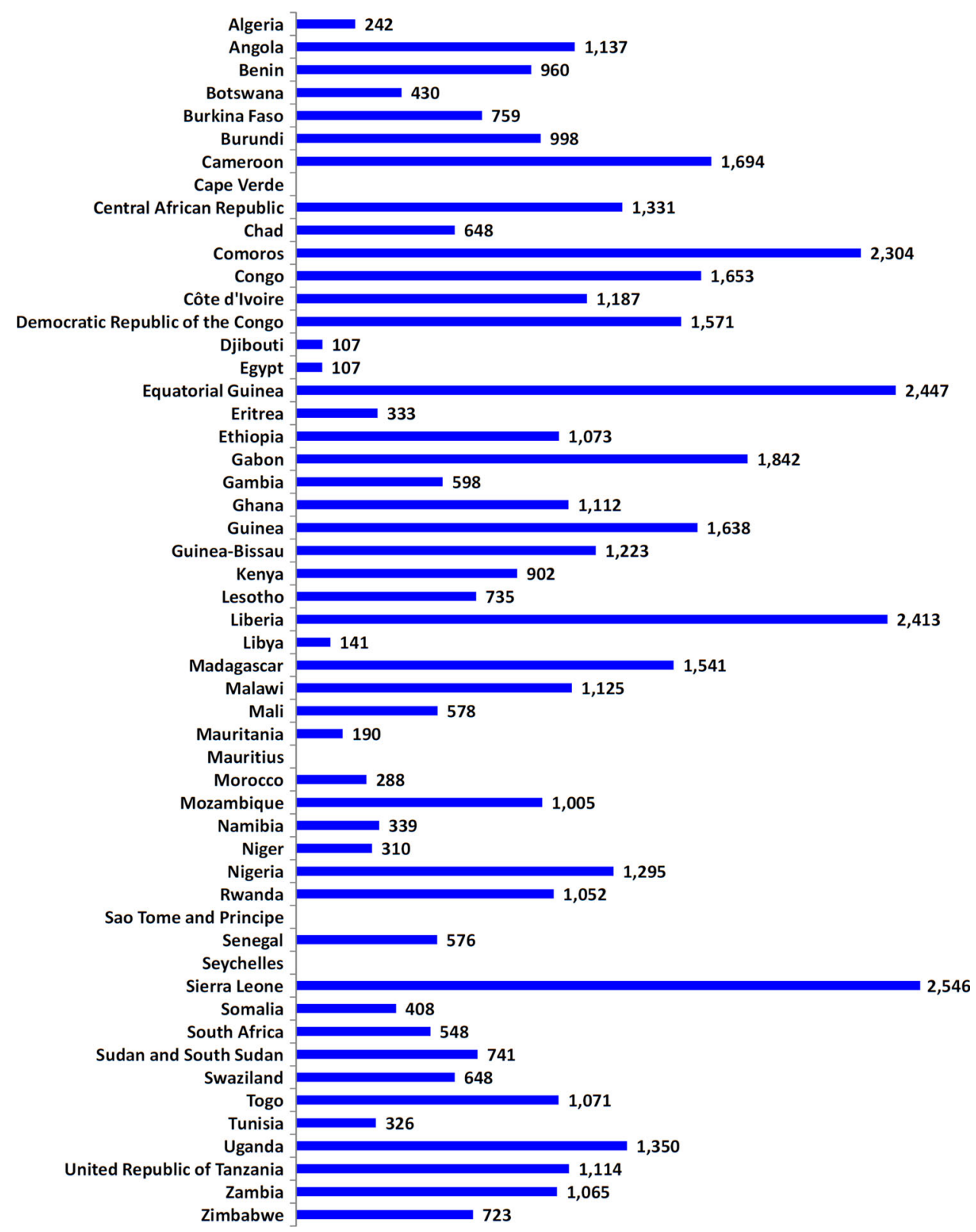

According to Fig. 1 value of permanent crops to cultivated area is $<40 \%$ for Central Africa (with the exception of Sao Tome and Principe $82 \%$ ), it is $<30 \%$ for Northern Africa (with the exception of Tunisia $46 \%$ ), Eastern Africa (with the exception of Burundi $30 \%$ ), and Gulf of Guinea (with the exception of Côte d'Ivoire $60 \%$ and Ghana $37 \%$ ), and it is close to zero for Sudano-Sahelian and Southern Africa. Figure 2 shows values of rural population to total population in 2011.

According to Fig. 2 the value of rural population to total population is $<50 \%$ for Northern Africa (with the exception of Egypt $56 \%$ ). This index is more than $40 \%$ for Sudano-Sahelian (with the exception of Cape Verde $38 \%$ area in 2011. 
Fig. 6 Value added to GDP by agriculture (\%) in 2011, this index is not available for Somalia (in few cases due to lack of data, value of the index in the previous years has been reported)

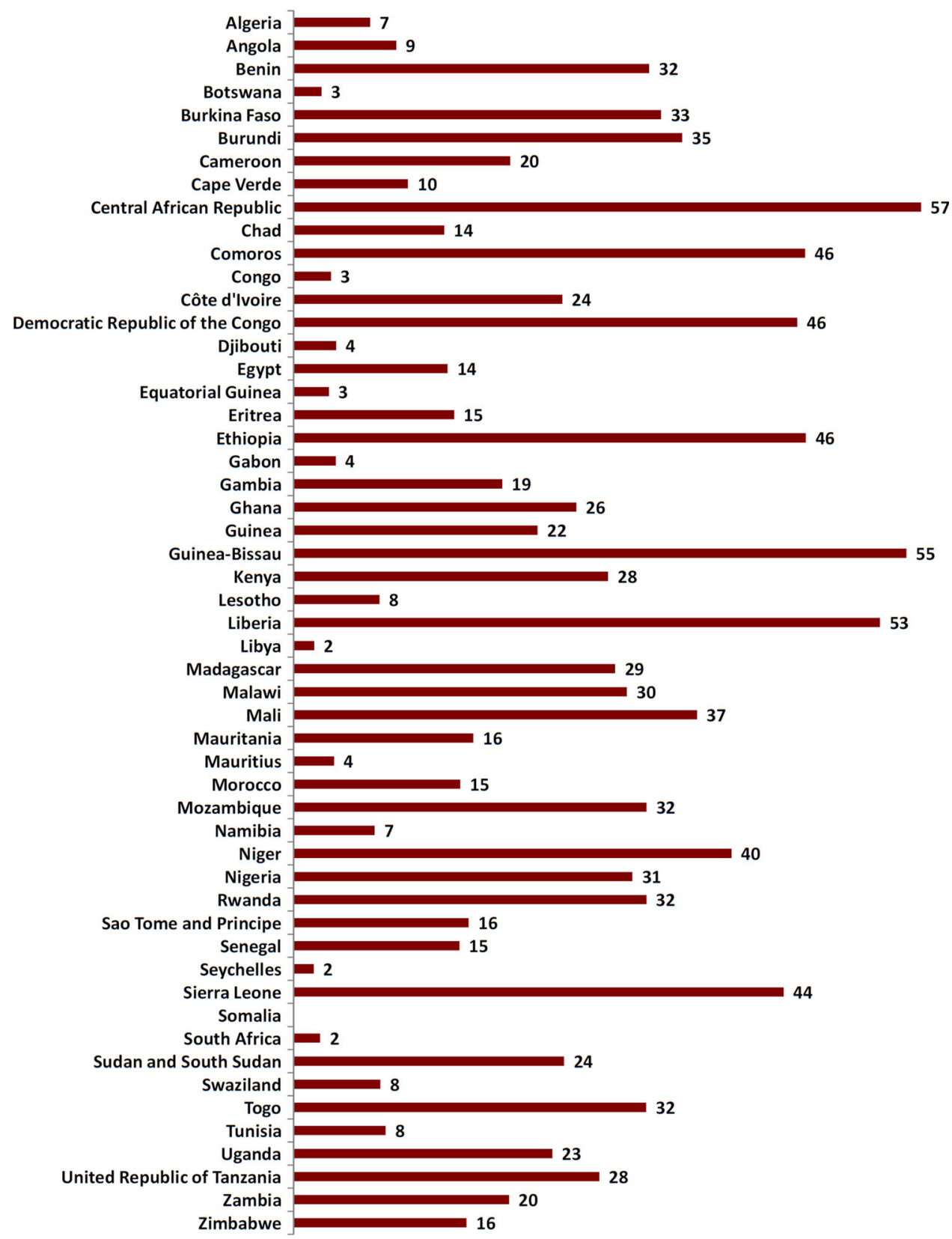

and Djibouti $24 \%$ ), Indian Ocean Islands, and Gulf of Guinea, it is more than $60 \%$ for Southern Africa (with the exception of Botswana $38 \%$ and South Africa $38 \%$ ), and it is more than $70 \%$ for Eastern Africa. Figure 3 shows total economically active population in agriculture to total economically active population in 2011 .

According to Fig. 3 value of economically active population in agriculture is $<30 \%$ for Northern Africa. This index is more than $60 \%$ for Eastern Africa and Indian Ocean Islands (with the exception of Mauritius $8 \%$ ), it is more than $50 \%$ for Sudano-Sahelian (with the exception of Cape Verde $16 \%$ and Mauritania $50 \%$ ), and it is more than $40 \%$ for Gulf of Guinea (with the exception of Côte
d'Ivoire $37 \%$ and Nigeria $24 \%$ ) and Central Africa (with the exception of Congo $31 \%$ and Gabon $25 \%$ ). Figure 4 shows values of HDI in 2011.

The value of HDI is more than 0.600 for Northern Africa (with the exception of Morocco 0.591). This index is $<0.600$ for Central Africa (with the exception of Gabon 0.683 ) and it is $<0.500$ for Sudano-Sahelian (with the exception of Cape Verde 0.586), Eastern Africa (with the exception of Kenya 0.519), and Gulf of Guinea (with the exception of Ghana 0.558). Figure 5 shows values of NRI in 2011.

According to Fig. 5, value of the NRI is $<300 \mathrm{~mm} /$ year for Northern Africa (with the exception of Tunisia 
Fig. 7 Irrigation water requirement (mm/year) in 2011 (in few cases due to lack of data, value of the index in the previous years has been reported)

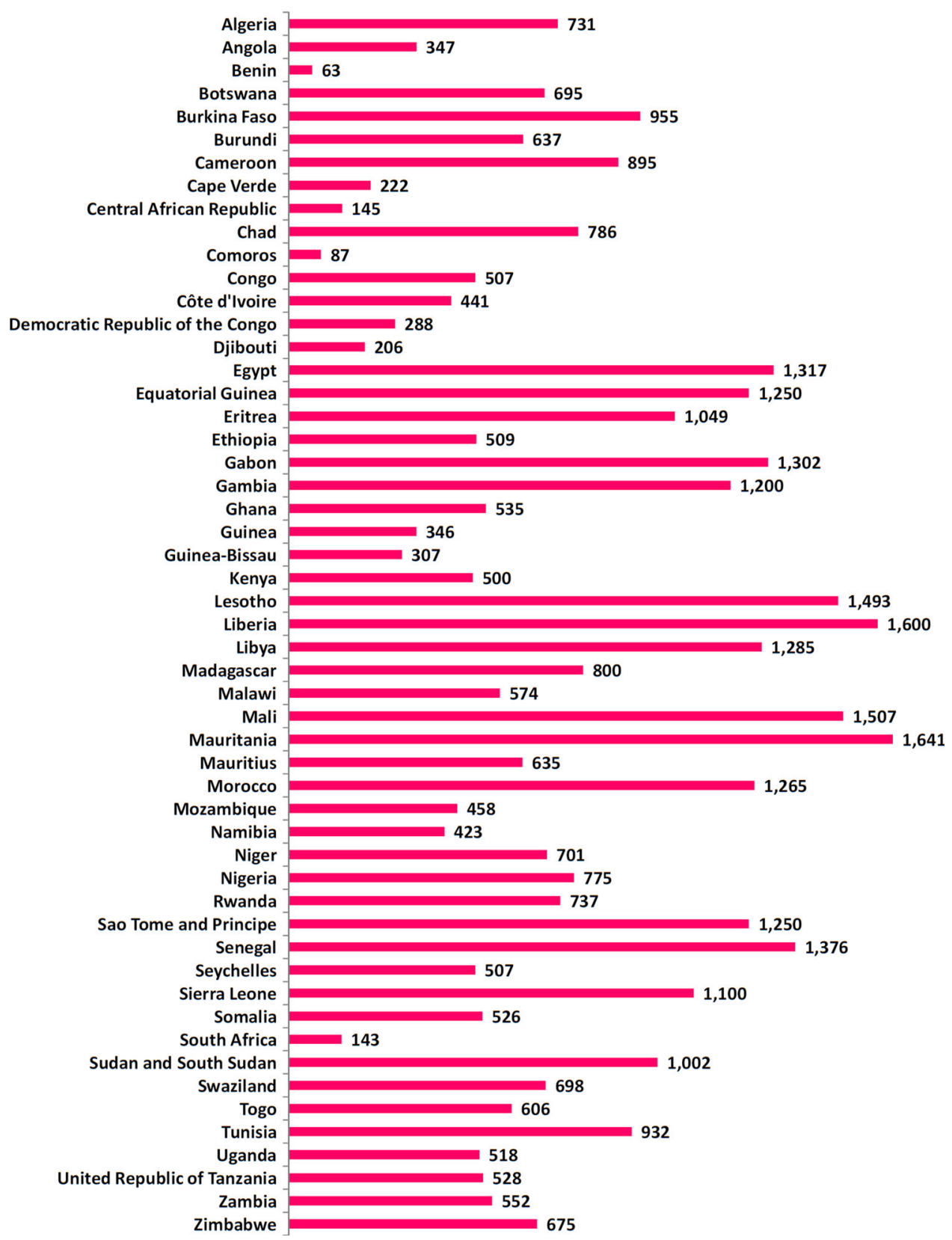

Mozambique $32 \%$ ). Figure 7 shows values of irrigation water requirement in 2011.

According to Fig. 7, value of irrigation water requirement is more than $1,000 \mathrm{~mm} / \mathrm{year}$ for Northern Africa (with the exception of Algeria $731 \mathrm{~mm} /$ year and Tunisia $932 \mathrm{~mm} /$ year), and it is more than $500 \mathrm{~mm} /$ year for Central Africa (with the exception of Central African Republic $145 \mathrm{~mm} / \mathrm{year}$ and Democratic Republic of the Congo $288 \mathrm{~mm} /$ year), Eastern Africa (with the exception of Kenya $500 \mathrm{~mm} / \mathrm{year}$ ), and Indian Ocean Islands (with the exception of Comoros $87 \mathrm{~mm} /$ year). Figure 8 shows value of percentage of total cultivated area drained in 2011 . Africa (with the exception of Malawi $30 \%$ and 
Fig. 8 Percentage of total cultivated area drained (\%) in 2011 (in few cases due to lack of data, value of the index in the previous years has been reported)

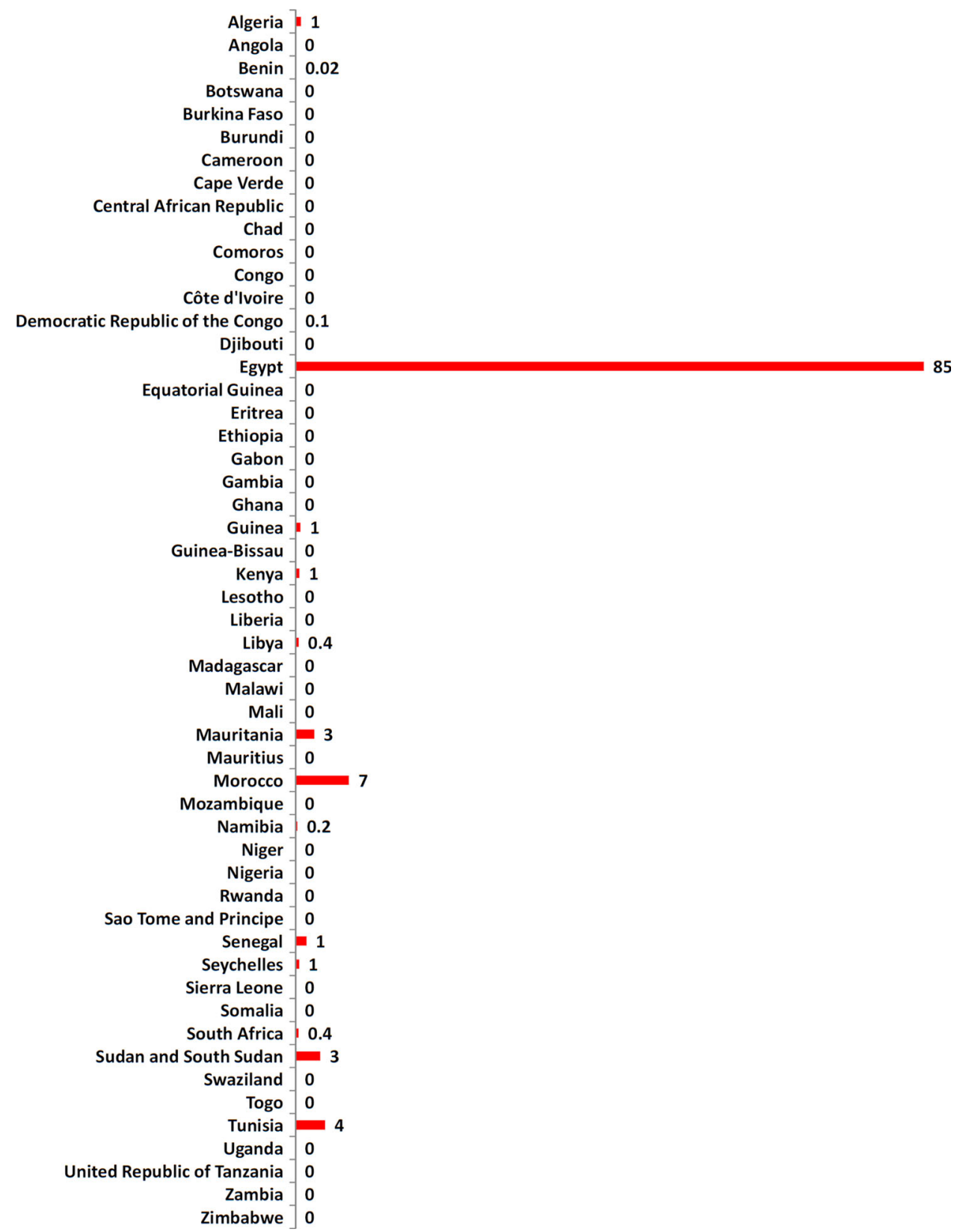

According to Fig. 8, drainage is close to zero for Africa (with the exception of Egypt $85 \%$ ). Previous studies notify the influence of drainage on subirrigation (Valero et al. 2007), crop productivity (Ale et al. 2009), improving water management (Ayars et al. 2006), and water balance (Turunen et al. 2013). Figure 9 shows value of difference between NRI and irrigation water requirement in 2011.

In the Fig. 9, value of difference between NRI and irrigation water requirement is positive for Gulf of Guinea, Central Africa, Eastern Africa, and Indian Ocean Islands. This index is negative for Northern Africa (with the exception of Libya $1,145 \mathrm{~mm} /$ year) and Sudano-Sahelian. The index is known as water deficit and the countries with negative values of that have a critical status for water resources management (Hussain et al. 2007; Jury and Vaux Jr. 2007; Ogilvie et al. 2010; Pfister et al. 2011; Qadir et al. 2007; Traore and Fontane 2007; Valipour et al. 2012a, b, 2013). Figure 10 shows value of land use policy index in 2011 (see also Burney et al. 2013; FAO 2011a, b; UNEP 2010).

According to Fig. 10, value of land use policy index is poor for Africa (with the exception of Egypt and Djibouti $100 \%$ ). The different aspects of irrigation in agricultural water management such as irrigation efficiency (Valipour 2013d; Valipour and Montazar 2012a, b, c), soil salinity (du Plessis 1985), water-saving (Montenegro et al. 2010), 
Fig. 9 Difference between NRI and irrigation water requirement ( $\mathrm{mm} /$ year) in 2011, this index is not available for Cape Verde, Mauritius, Sao Tome and Principe, and Seychelles (in few cases due to lack of data, value of the index in the previous years has been reported)

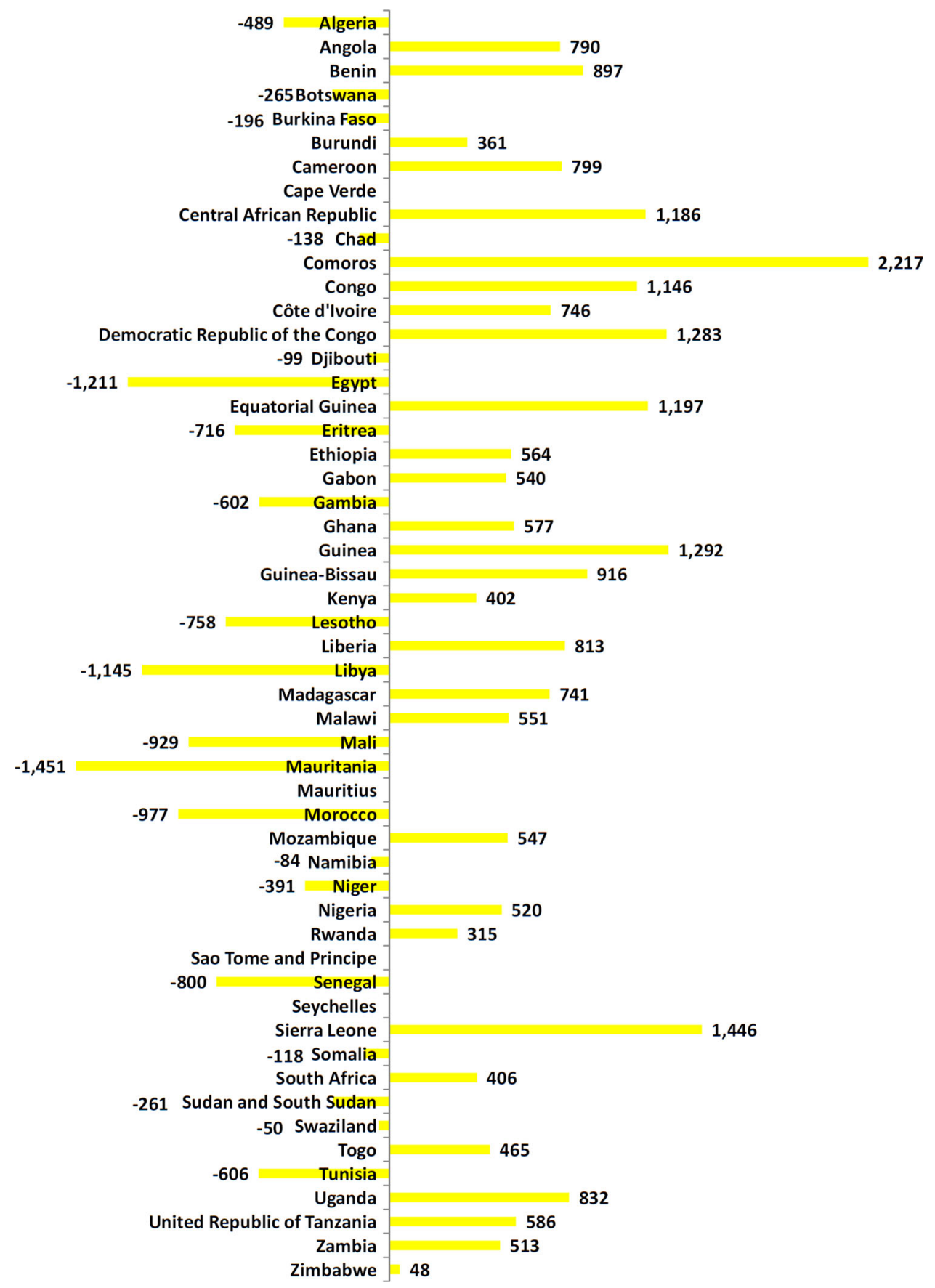

sustainable development (Schultz and De Wrachien 2002; Valipour 2014a, b, c), soil water management (Steiner and Keller 1992), and crop yield (Wu et al. 2013) have been investigated in the previous works. Also, FAO (2011a, b) showed that pressure on water resources would be increased by 2050 due to irrigation and land use policies. Figure 11 is applied to summarize the results of Figs. 1-10.

If we accept the negative role of NRI (the fifth index) and difference between NRI and irrigation water requirement (the ninth index) and the positive role of the other main indices on land use policy index (tenth index) based on the Eqs 9 and 10 (with the assumption that reduction of fifth and ninth indices, increases tenth index and increase of the other main indices, increases the tenth index), the Fig. 11 will be interpretable. In the Fig. 11a, values of HDI, NRI, irrigation water requirement, and difference between NRI and irrigation water requirement are suitable but value of land use policy index is not suitable, therefore role of permanent crops to cultivated area, rural population to total population, total economically active population in 
Fig. 10 Land use policy index $(\%)$ in 2011 (in few cases due to lack of data, value of the index in the previous years has been reported)

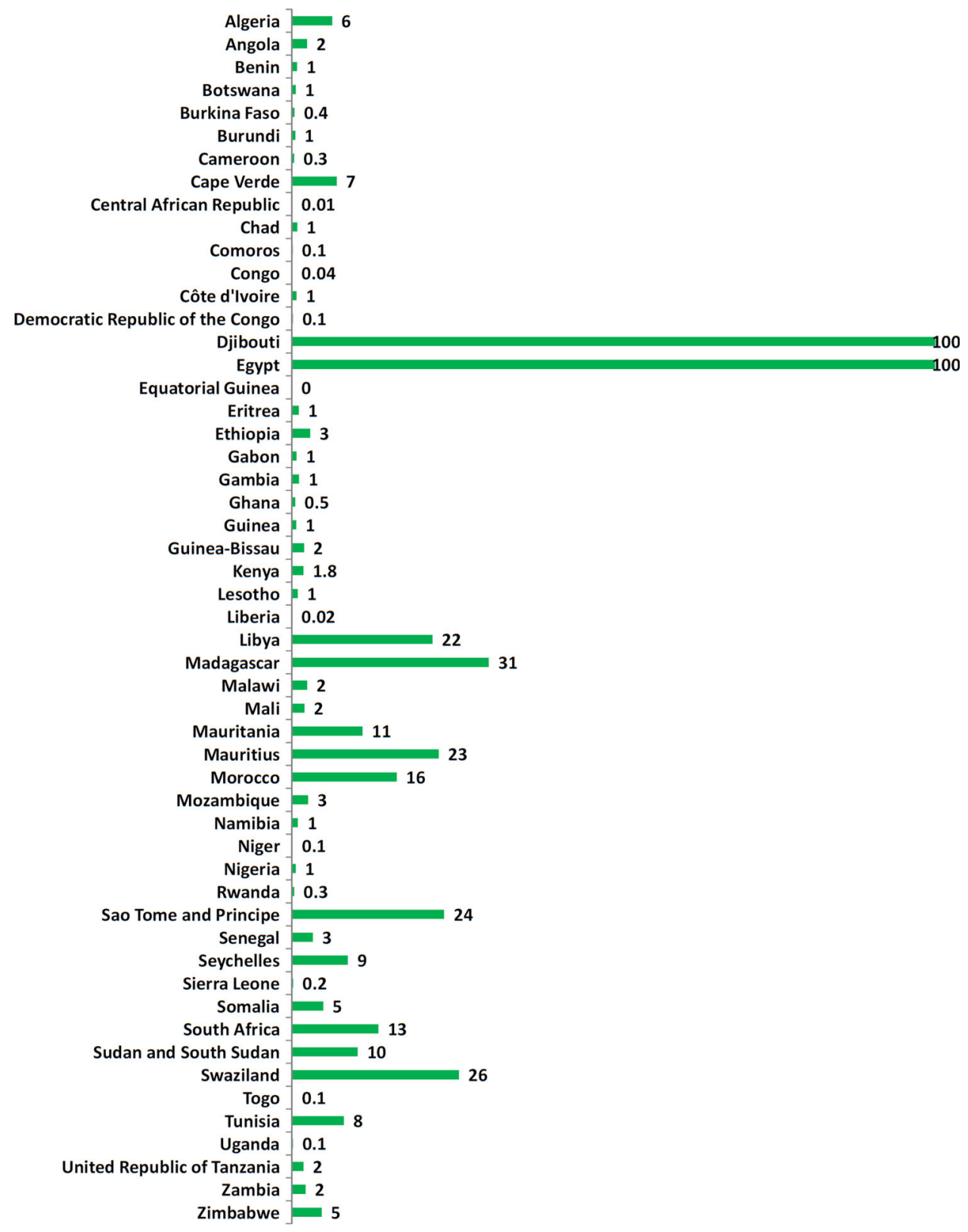

agriculture to total economically active population, value added to GDP by agriculture, and percentage of total cultivated area drained can be effective on the tenth index in Northern Africa. In the Fig. 11b, values of rural population to total population, total economically active population in agriculture to total economically active population, irrigation water requirement, and difference between NRI and irrigation water requirement are suitable but value of land use policy index is not suitable, thus role of permanent crops to cultivated area, HDI, NRI, and percentage of total cultivated area drained can be effective on the tenth index in Sudano-Sahelian. In the Fig. 11c, values of rural population to total population, total economically active population in agriculture to total economically active population, and irrigation water requirement are suitable but value of land use policy index is not suitable, since role of permanent crops to cultivated area, HDI, NRI, and percentage of total cultivated area drained can be effective on the tenth index in Gulf of Guinea. In the Fig. 11d, values of total economically active population in agriculture to total economically active population and irrigation water requirement are suitable but value of land use policy index is not suitable, as role of permanent crops to cultivated area, HDI, value added to GDP by agriculture, and percentage of total cultivated area drained can be effective on the tenth index in Central Africa. In Fig. 11e, value of 
(a) Northern Africa

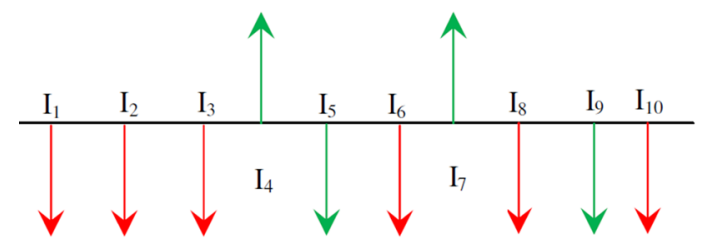

(c) Gulf of Guinea

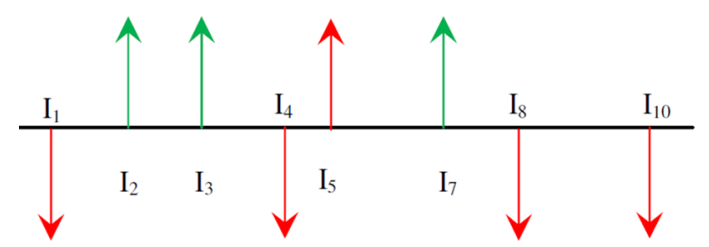

(e) Eastern Africa

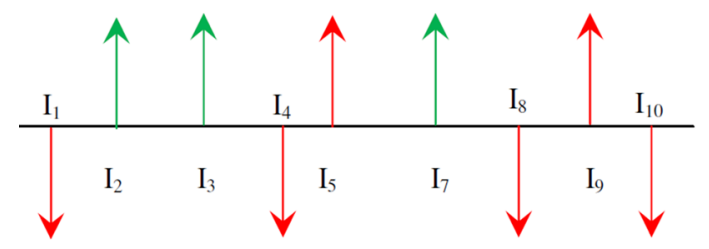

(g) Indian Ocean Islands

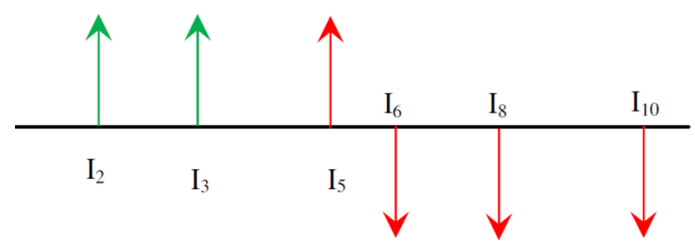

Fig. 11 A binary (qualitative) diagram to specify status of the main indices in different regions of Africa (ignore the exceptions), $I_{1}$ indicates permanent crops to cultivated area, $I_{2}$ indicates rural population to total population, $I_{3}$ indicates total economically active population in agriculture to total economically active population, $I_{4}$

rural population to total population, total economically active population in agriculture to total economically active population, and irrigation water requirement are suitable but value of land use policy index is not suitable, therefore role of permanent crops to cultivated area, HDI, NRI, percentage of total cultivated area drained, and difference between NRI and irrigation water requirement can be effective on the tenth index in Eastern Africa. In the Fig. 11f, values of rural population to total population, irrigation water requirement, and percentage of total cultivated area drained are suitable but value of land use (b) Sudano-Sahelian

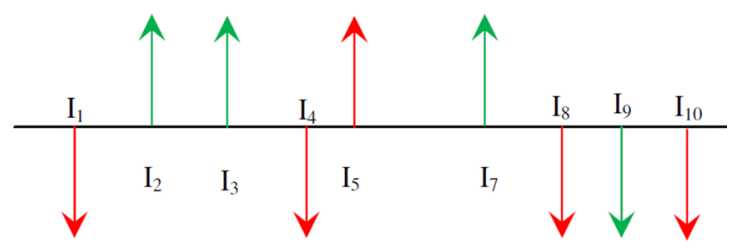

(d) Central Africa

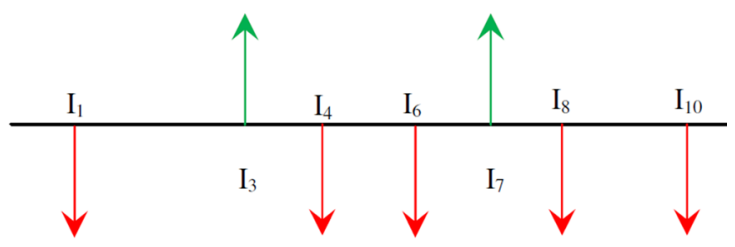

(f) Southern Africa

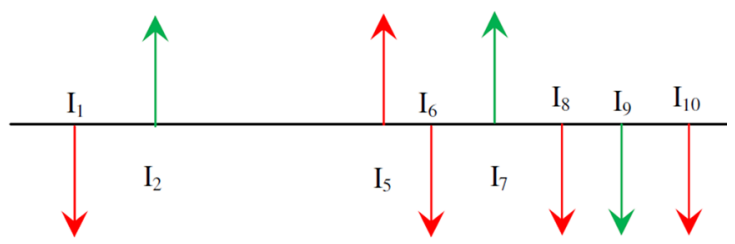

indicates HDI, $I_{5}$ indicates NRI, $I_{6}$ indicates value added to GDP by agriculture, $I_{7}$ indicates Irrigation water requirement, $I_{8}$ indicates percentage of total cultivated area drained, $I_{9}$ indicates difference between NRI and irrigation water requirement, and $I_{10}$ indicates land use policy index

policy index is not suitable, thus role of permanent crops to cultivated area, NRI, value added to GDP by agriculture, and percentage of total cultivated area drained can be effective on the tenth index in Southern Africa. In the Fig. $11 \mathrm{~g}$, values of rural population to total population and total economically active population in agriculture to total economically active population are suitable but value of land use policy index is not suitable, since role of NRI, value added to GDP by agriculture and percentage of total cultivated area drained can be effective on the tenth index in Indian Ocean Islands. As was observed from the Figs. 1-10, 
Table 1 Estimated functions using the first method (Eq. 9) for value of land use policy index in Africa (52 countries), this function is not calculable for Equatorial Guinea due to very poor irrigation

\begin{tabular}{|c|c|}
\hline Country & Suggested formula to estimate value of area equipped for irrigation to cultivated area (\%) \\
\hline Algeria & $\begin{array}{l}I_{10}=0.017 I_{n 1}+0.091 I_{n 2}+0.036 I_{n 3}+0.216 I_{n 4}-0.205 I_{n 5}+0.015 I_{n 6}+0.042 I_{n 7}+0.001 I_{n 8}- \\
0.377 I_{n 9}+58.170\end{array}$ \\
\hline Angola & $I_{10}=0.039 I_{n 1}+0.149 I_{n 2}+0.106 I_{n 3}+0.116 I_{n 4}-0.126 I_{n 5}+0.173 I_{n 6}+0.147 I_{n 7}-0.145 I_{n 9}+27.053$ \\
\hline Benin & $\begin{array}{l}I_{10}=0.250 I_{n 1}+0.106 I_{n 2}+0.112 I_{n 3}+0.109 I_{n 4}-0.106 I_{n 5}+0.108 I_{n 6}+0.104 I_{n 7}+0.0003 I_{n 8}- \\
0.104 I_{n 9}+21.086\end{array}$ \\
\hline Botswana & $I_{10}=0.019 I_{n 1}+0.116 I_{n 2}+0.115 I_{n 3}+0.108 I_{n 4}-0.108 I_{n 5}+0.304 I_{n 6}+0.119 I_{n 7}-0.111 I_{n 9}+21.903$ \\
\hline Burkina Faso & $I_{10}=0.067 I_{n 1}+0.130 I_{n 2}+0.129 I_{n 3}+0.136 I_{n 4}-0.131 I_{n 5}+0.133 I_{n 6}+0.140 I_{n 7}-0.135 I_{n 9}+26.578$ \\
\hline Burundi & $I_{10}=0.131 I_{n 1}+0.119 I_{n 2}+0.120 I_{n 3}+0.128 I_{n 4}-0.124 I_{n 5}+0.123 I_{n 6}+0.128 I_{n 7}-0.126 I_{n 9}+56.006$ \\
\hline Cameroon & $I_{10}=0.134 I_{n 1}+0.124 I_{n 2}+0.123 I_{n 3}+0.121 I_{n 4}-0.127 I_{n 5}+0.127 I_{n 6}+0.121 I_{n 7}-0.124 I_{n 9}+25.069$ \\
\hline Cape Verde & $I_{10}=0.004 I_{n 1}+0.053 I_{n 2}+0.011 I_{n 3}+0.748 I_{n 4}+0.012 I_{n 6}+0.172 I_{n 7}$ \\
\hline Central African Republic & $I_{10}=0.126 I_{n 1}+0.125 I_{n 2}+0.125 I_{n 3}+0.125 I_{n 4}-0.125 I_{n 5}+0.125 I_{n 6}+0.125 I_{n 7}-0.125 I_{n 9}+24.968$ \\
\hline Chad & $I_{10}=0.013 I_{n 1}+0.130 I_{n 2}+0.132 I_{n 3}+0.145 I_{n 4}-0.131 I_{n 5}+0.177 I_{n 6}+0.139 I_{n 7}-0.134 I_{n 9}+26.530$ \\
\hline Comoros & $I_{10}=0.140 I_{n 1}+0.139 I_{n 2}+0.139 I_{n 3}+0.140 I_{n 4}-0.156 I_{n 5}+0.139 I_{n 6}+0.146 I_{n 7}+15.620$ \\
\hline Congo & $I_{10}=0.126 I_{n 1}+0.124 I_{n 2}+0.124 I_{n 3}+0.123 I_{n 4}-0.124 I_{n 5}+0.131 I_{n 6}+0.123 I_{n 7}-0.124 I_{n 9}+24.775$ \\
\hline Côte d'Ivoire & $I_{10}=0.120 I_{n 1}+0.125 I_{n 2}+0.132 I_{n 3}+0.125 I_{n 4}-0.125 I_{n 5}+0.130 I_{n 6}+0.121 I_{n 7}-0.122 I_{n 9}+24.735$ \\
\hline $\begin{array}{l}\text { Democratic Republic of the } \\
\text { Congo }\end{array}$ & $\begin{array}{l}I_{10}=0.134 I_{n 1}+0.122 I_{n 2}+0.122 I_{n 3}+0.124 I_{n 4}-0.124 I_{n 5}+0.121 I_{n 6}+0.123 I_{n 7}+0.006 I_{n 8}- \\
\quad 0.124 I_{n 9}+24.795\end{array}$ \\
\hline Djibouti & $I_{10}=0.012 I_{n 2}+0.126 I_{n 3}+0.039 I_{n 4}-0.721 I_{n 5}+0.002 I_{n 6}+0.025 I_{n 7}-0.075 I_{n 9}+79.621$ \\
\hline Egypt & $\begin{array}{l}I_{10}=0.0002 I_{n 1}+0.001 I_{n 2}+0.0002 I_{n 3}+0.003 I_{n 4}-0.013 I_{n 5}+0.0002 I_{n 6}+0.0005 I_{n 7}+0.981 I_{n 8}- \\
0.001 I_{n 9}+1.470\end{array}$ \\
\hline Eritrea & $I_{10}=0.004 I_{n 1}+0.125 I_{n 2}+0.127 I_{n 3}+0.145 I_{n 4}-0.126 I_{n 5}+0.187 I_{n 6}+0.152 I_{n 7}-0.133 I_{n 9}+25.898$ \\
\hline Ethiopia & $I_{10}=0.019 I_{n 1}+0.061 I_{n 2}+0.064 I_{n 3}+0.100 I_{n 4}-0.083 I_{n 5}+0.065 I_{n 6}+0.442 I_{n 7}-0.167 I_{n 9}+24.972$ \\
\hline Gabon & $I_{10}=0.036 I_{n 1}+0.056 I_{n 2}+0.041 I_{n 3}+0.033 I_{n 4}-0.041 I_{n 5}+0.717 I_{n 6}+0.036 I_{n 7}-0.040 I_{n 9}+8.074$ \\
\hline Gambia & $I_{10}=0.013 I_{n 1}+0.123 I_{n 2}+0.108 I_{n 3}+0.117 I_{n 4}-0.109 I_{n 5}+0.140 I_{n 6}+0.259 I_{n 7}-0.130 I_{n 9}+23.927$ \\
\hline Ghana & $\mathrm{I}_{10}=0.128 \mathrm{I}_{\mathrm{n} 1}+0.125 \mathrm{I}_{\mathrm{n} 2}+0.124 \mathrm{I}_{\mathrm{n} 3}+0.123 \mathrm{I}_{\mathrm{n} 4}-0.125 \mathrm{I}_{\mathrm{n} 5}+0.128 \mathrm{I}_{\mathrm{n} 6}+0.123 \mathrm{I}_{\mathrm{n} 7}-0.124 \mathrm{I}_{\mathrm{n} 9}+24.853$ \\
\hline Guinea & $\begin{array}{l}\mathrm{I}_{10}=0.146 \mathrm{I}_{\mathrm{n} 1}+0.115 \mathrm{I}_{\mathrm{n} 2}+0.113 \mathrm{I}_{\mathrm{n} 3}+0.123 \mathrm{I}_{\mathrm{n} 4}-0.129 \mathrm{I}_{\mathrm{n} 5}+0.127 \mathrm{I}_{\mathrm{n} 6}+0.114 \mathrm{I}_{\mathrm{n} 7}+0.014 \mathrm{I}_{\mathrm{n} 8}- \\
0.118 \mathrm{I}_{\mathrm{n} 9}+24.723\end{array}$ \\
\hline Guinea-Bissau & $\mathrm{I}_{10}=0.134 \mathrm{I}_{\mathrm{n} 1}+0.116 \mathrm{I}_{\mathrm{n} 2}+0.113 \mathrm{I}_{\mathrm{n} 3}+0.151 \mathrm{I}_{\mathrm{n} 4}-0.138 \mathrm{I}_{\mathrm{n} 5}+0.110 \mathrm{I}_{\mathrm{n} 6}+0.116 \mathrm{I}_{\mathrm{n} 7}-0.122 \mathrm{I}_{\mathrm{n} 9}+26.038$ \\
\hline Kenya & $\begin{array}{l}\mathrm{I}_{10}=0.190 \mathrm{I}_{\mathrm{n} 1}+0.091 \mathrm{I}_{\mathrm{n} 2}+0.094 \mathrm{I}_{\mathrm{n} 3}+0.100 \mathrm{I}_{\mathrm{n} 4}-0.100 \mathrm{I}_{\mathrm{n} 5}+0.112 \mathrm{I}_{\mathrm{n} 6}+0.184 \mathrm{I}_{\mathrm{n} 7}+0.003 \mathrm{I}_{\mathrm{n} 8}- \\
0.128 \mathrm{I}_{\mathrm{n} 9}+22.785\end{array}$ \\
\hline Lesotho & $\mathrm{I}_{10}=0.021 \mathrm{I}_{\mathrm{n} 1}+0.109 \mathrm{I}_{\mathrm{n} 2}+0.123 \mathrm{I}_{\mathrm{n} 3}+0.115 \mathrm{I}_{\mathrm{n} 4}-0.111 \mathrm{I}_{\mathrm{n} 5}+0.268 \mathrm{I}_{\mathrm{n} 6}+0.133 \mathrm{I}_{\mathrm{n} 7}-0.120 \mathrm{I}_{\mathrm{n} 9}+23.046$ \\
\hline Liberia & $\mathrm{I}_{10}=0.125 \mathrm{I}_{\mathrm{n} 1}+0.124 \mathrm{I}_{\mathrm{n} 2}+0.124 \mathrm{I}_{\mathrm{n} 3}+0.125 \mathrm{I}_{\mathrm{n} 4}-0.128 \mathrm{I}_{\mathrm{n} 5}+0.124 \mathrm{I}_{\mathrm{n} 6}+0.124 \mathrm{I}_{\mathrm{n} 7}-0.125 \mathrm{I}_{\mathrm{n} 9}+25.319$ \\
\hline Libya & $\begin{array}{l}\mathrm{I}_{10}=0.012 \mathrm{I}_{\mathrm{n} 1}+0.016 \mathrm{I}_{\mathrm{n} 2}+0.001 \mathrm{I}_{\mathrm{n} 3}+0.134 \mathrm{I}_{\mathrm{n} 4}-0.138 \mathrm{I}_{\mathrm{n} 5}+0.001 \mathrm{I}_{\mathrm{n} 6}+0.048 \mathrm{I}_{\mathrm{n} 7}+0.0002 \mathrm{I}_{\mathrm{n} 8}- \\
\quad 0.650 \mathrm{I}_{\mathrm{n} 9}+78.777\end{array}$ \\
\hline Madagascar & $\mathrm{I}_{10}=0.002 \mathrm{I}_{\mathrm{n} 1}+0.325 \mathrm{I}_{\mathrm{n} 2}+0.605 \mathrm{I}_{\mathrm{n} 3}+0.023 \mathrm{I}_{\mathrm{n} 4}-0.007 \mathrm{I}_{\mathrm{n} 5}+0.013 \mathrm{I}_{\mathrm{n} 6}+0.017 \mathrm{I}_{\mathrm{n} 7}-0.008 \mathrm{I}_{\mathrm{n} 9}+1.528$ \\
\hline Malawi & $\mathrm{I}_{10}=0.018 \mathrm{I}_{\mathrm{n} 1}+0.109 \mathrm{I}_{\mathrm{n} 2}+0.111 \mathrm{I}_{\mathrm{n} 3}+0.147 \mathrm{I}_{\mathrm{n} 4}-0.139 \mathrm{I}_{\mathrm{n} 5}+0.144 \mathrm{I}_{\mathrm{n} 6}+0.169 \mathrm{I}_{\mathrm{n} 7}-0.163 \mathrm{I}_{\mathrm{n} 9}+30.218$ \\
\hline Mali & $\mathrm{I}_{10}=0.012 \mathrm{I}_{\mathrm{n} 1}+0.135 \mathrm{I}_{\mathrm{n} 2}+0.129 \mathrm{I}_{\mathrm{n} 3}+0.181 \mathrm{I}_{\mathrm{n} 4}-0.131 \mathrm{I}_{\mathrm{n} 5}+0.141 \mathrm{I}_{\mathrm{n} 6}+0.139 \mathrm{I}_{\mathrm{n} 7}-0.133 \mathrm{I}_{\mathrm{n} 9}+26.366$ \\
\hline Mauritania & $\begin{array}{l}\mathrm{I}_{10}=0.0002 \mathrm{I}_{\mathrm{n} 1}+0.023 \mathrm{I}_{\mathrm{n} 2}+0.878 \mathrm{I}_{\mathrm{n} 3}+0.068 \mathrm{I}_{\mathrm{n} 4}-0.009 \mathrm{I}_{\mathrm{n} 5}+0.004 \mathrm{I}_{\mathrm{n} 6}+0.010 \mathrm{I}_{\mathrm{n} 7}+0.0002 \mathrm{I}_{\mathrm{n} 8}- \\
\quad 0.008 \mathrm{I}_{\mathrm{n} 9}+1.730\end{array}$ \\
\hline Mauritius & $\mathrm{I}_{10}=0.006 \mathrm{I}_{\mathrm{n} 1}+0.455 \mathrm{I}_{\mathrm{n} 2}+0.010 \mathrm{I}_{\mathrm{n} 3}+0.444 \mathrm{I}_{\mathrm{n} 4}+0.007 \mathrm{I}_{\mathrm{n} 6}+0.078 \mathrm{I}_{\mathrm{n} 7}$ \\
\hline Morocco & $\begin{array}{l}\mathrm{I}_{10}=0.008 \mathrm{I}_{\mathrm{n} 1}+0.045 \mathrm{I}_{\mathrm{n} 2}+0.017 \mathrm{I}_{\mathrm{n} 3}+0.311 \mathrm{I}_{\mathrm{n} 4}-0.419 \mathrm{I}_{\mathrm{n} 5}+0.017 \mathrm{I}_{\mathrm{n} 6}+0.039 \mathrm{I}_{\mathrm{n} 7}+0.004 \mathrm{I}_{\mathrm{n} 8}- \\
0.140 \mathrm{I}_{\mathrm{n} 9}+55.919\end{array}$ \\
\hline Mozambique & $\mathrm{I}_{10}=0.015 \mathrm{I}_{\mathrm{n} 1}+0.108 \mathrm{I}_{\mathrm{n} 2}+0.096 \mathrm{I}_{\mathrm{n} 3}+0.179 \mathrm{I}_{\mathrm{n} 4}-0.116 \mathrm{I}_{\mathrm{n} 5}+0.123 \mathrm{I}_{\mathrm{n} 6}+0.205 \mathrm{I}_{\mathrm{n} 7}-0.158 \mathrm{I}_{\mathrm{n} 9}+27.479$ \\
\hline Namibia & $\begin{array}{l}\mathrm{I}_{10}=0.016 \mathrm{I}_{\mathrm{n} 1}+0.107 \mathrm{I}_{\mathrm{n} 2}+0.124 \mathrm{I}_{\mathrm{n} 3}+0.105 \mathrm{I}_{\mathrm{n} 4}-0.103 \mathrm{I}_{\mathrm{n} 5}+0.328 \mathrm{I}_{\mathrm{n} 6}+0.109 \mathrm{I}_{\mathrm{n} 7}+0.003 \mathrm{I}_{\mathrm{n} 8}- \\
0.105 \mathrm{I}_{\mathrm{n} 9}+20.827\end{array}$ \\
\hline Niger & $\mathrm{I}_{10}=0.140 \mathrm{I}_{\mathrm{n} 1}+0.123 \mathrm{I}_{\mathrm{n} 2}+0.123 \mathrm{I}_{\mathrm{n} 3}+0.124 \mathrm{I}_{\mathrm{n} 4}-0.123 \mathrm{I}_{\mathrm{n} 5}+0.123 \mathrm{I}_{\mathrm{n} 6}+0.123 \mathrm{I}_{\mathrm{n} 7}-0.122 \mathrm{I}_{\mathrm{n} 9}+24.507$ \\
\hline Nigeria & $\mathrm{I}_{10}=0.230 \mathrm{I}_{\mathrm{n} 1}+0.105 \mathrm{I}_{\mathrm{n} 2}+0.121 \mathrm{I}_{\mathrm{n} 3}+0.105 \mathrm{I}_{\mathrm{n} 4}-0.107 \mathrm{I}_{\mathrm{n} 5}+0.106 \mathrm{I}_{\mathrm{n} 6}+0.114 \mathrm{I}_{\mathrm{n} 7}-0.113 \mathrm{I}_{\mathrm{n} 9}+22.011$ \\
\hline Rwanda & $\mathrm{I}_{10}=0.139 \mathrm{I}_{\mathrm{n} 1}+0.120 \mathrm{I}_{\mathrm{n} 2}+0.120 \mathrm{I}_{\mathrm{n} 3}+0.124 \mathrm{I}_{\mathrm{n} 4}-0.123 \mathrm{I}_{\mathrm{n} 5}+0.123 \mathrm{I}_{\mathrm{n} 6}+0.126 \mathrm{I}_{\mathrm{n} 7}-0.125 \mathrm{I}_{\mathrm{n} 9}+24.799$ \\
\hline Sao Tome and Principe & $\mathrm{I}_{10}=0.299 \mathrm{I}_{\mathrm{n} 1}+0.071 \mathrm{I}_{\mathrm{n} 2}+0.227 \mathrm{I}_{\mathrm{n} 3}+0.296 \mathrm{I}_{\mathrm{n} 4}+0.034 \mathrm{I}_{\mathrm{n} 6}+0.074 \mathrm{I}_{\mathrm{n} 7}$ \\
\hline
\end{tabular}


Table 1 continued

\begin{tabular}{|c|c|}
\hline Country & Suggested formula to estimate value of area equipped for irrigation to cultivated area (\%) \\
\hline Senegal & $\begin{array}{l}\mathrm{I}_{10}=0.004 \mathrm{I}_{\mathrm{n} 1}+0.133 \mathrm{I}_{\mathrm{n} 2}+0.115 \mathrm{I}_{\mathrm{n} 3}+0.149 \mathrm{I}_{\mathrm{n} 4}-0.114 \mathrm{I}_{\mathrm{n} 5}+0.286 \mathrm{I}_{\mathrm{n} 6}+0.098 \mathrm{I}_{\mathrm{n} 7}+0.004 \mathrm{I}_{\mathrm{n} 8}- \\
\quad 0.098 \mathrm{I}_{\mathrm{n} 9}+21.202\end{array}$ \\
\hline Seychelles & $\mathrm{I}_{10}=0.428 \mathrm{I}_{\mathrm{n} 1}+0.037 \mathrm{I}_{\mathrm{n} 2}+0.315 \mathrm{I}_{\mathrm{n} 3}+0.212 \mathrm{I}_{\mathrm{n} 4}+0.001 \mathrm{I}_{\mathrm{n} 6}+0.007 \mathrm{I}_{\mathrm{n} 7}+0.0002 \mathrm{I}_{\mathrm{n} 8}$ \\
\hline Sierra Leone & $\mathrm{I}_{10}=0.155 \mathrm{I}_{\mathrm{n} 1}+0.139 \mathrm{I}_{\mathrm{n} 2}+0.139 \mathrm{I}_{\mathrm{n} 3}+0.141 \mathrm{I}_{\mathrm{n} 4}+0.138 \mathrm{I}_{\mathrm{n} 6}+0.140 \mathrm{I}_{\mathrm{n} 7}-0.149 \mathrm{I}_{\mathrm{n} 9}+14.852$ \\
\hline Somalia & $\mathrm{I}_{10}=0.00002 \mathrm{I}_{\mathrm{n} 1}+0.001 \mathrm{I}_{\mathrm{n} 2}+0.001 \mathrm{I}_{\mathrm{n} 3}-0.001 \mathrm{I}_{\mathrm{n} 5}+0.996 \mathrm{I}_{\mathrm{n} 7}-0.001 \mathrm{I}_{\mathrm{n} 9}+0.208$ \\
\hline South Africa & $\begin{array}{l}\mathrm{I}_{10}=0.003 \mathrm{I}_{\mathrm{n} 1}+0.072 \mathrm{I}_{\mathrm{n} 2}+0.005 \mathrm{I}_{\mathrm{n} 3}+0.298 \mathrm{I}_{\mathrm{n} 4}-0.288 \mathrm{I}_{\mathrm{n} 5}+0.003 \mathrm{I}_{\mathrm{n} 6}+0.068 \mathrm{I}_{\mathrm{n} 7}+0.0003 \mathrm{I}_{\mathrm{n} 8}- \\
0.263 \mathrm{I}_{\mathrm{n} 9}+55.157\end{array}$ \\
\hline Sudan and South Sudan & $\begin{array}{l}\mathrm{I}_{10}=0.001 \mathrm{I}_{\mathrm{n} 1}+0.228 \mathrm{I}_{\mathrm{n} 2}+0.142 \mathrm{I}_{\mathrm{n} 3}+0.124 \mathrm{I}_{\mathrm{n} 4}-0.277 \mathrm{I}_{\mathrm{n} 5}+0.089 \mathrm{I}_{\mathrm{n} 6}+0.044 \mathrm{I}_{\mathrm{n} 7}+0.005 \mathrm{I}_{\mathrm{n} 8}- \\
0.089 \mathrm{I}_{\mathrm{n} 9}+36.657\end{array}$ \\
\hline Swaziland & $\mathrm{I}_{10}=0.002 \mathrm{I}_{\mathrm{n} 1}+0.791 \mathrm{I}_{\mathrm{n} 2}+0.009 \mathrm{I}_{\mathrm{n} 3}+0.054 \mathrm{I}_{\mathrm{n} 4}-0.101 \mathrm{I}_{\mathrm{n} 5}+0.003 \mathrm{I}_{\mathrm{n} 6}+0.014 \mathrm{I}_{\mathrm{n} 7}-0.027 \mathrm{I}_{\mathrm{n} 9}+12.784$ \\
\hline Togo & $\mathrm{I}_{10}=0.135 \mathrm{I}_{\mathrm{n} 1}+0.124 \mathrm{I}_{\mathrm{n} 2}+0.124 \mathrm{I}_{\mathrm{n} 3}+0.124 \mathrm{I}_{\mathrm{n} 4}-0.124 \mathrm{I}_{\mathrm{n} 5}+0.124 \mathrm{I}_{\mathrm{n} 6}+0.123 \mathrm{I}_{\mathrm{n} 7}-0.123 \mathrm{I}_{\mathrm{n} 9}+24.698$ \\
\hline Tunisia & $\begin{array}{l}\mathrm{I}_{10}=0.073 \mathrm{I}_{\mathrm{n} 1}+0.027 \mathrm{I}_{\mathrm{n} 2}+0.012 \mathrm{I}_{\mathrm{n} 3}+0.363 \mathrm{I}_{\mathrm{n} 4}-0.419 \mathrm{I}_{\mathrm{n} 5}+0.007 \mathrm{I}_{\mathrm{n} 6}+0.021 \mathrm{I}_{\mathrm{n} 7}+0.002 \mathrm{I}_{\mathrm{n} 8}- \\
0.076 \mathrm{I}_{\mathrm{n} 9}+49.477\end{array}$ \\
\hline Uganda & $\mathrm{I}_{10}=0.127 \mathrm{I}_{\mathrm{n} 1}+0.123 \mathrm{I}_{\mathrm{n} 2}+0.123 \mathrm{I}_{\mathrm{n} 3}+0.124 \mathrm{I}_{\mathrm{n} 4}-0.125 \mathrm{I}_{\mathrm{n} 5}+0.125 \mathrm{I}_{\mathrm{n} 6}+0.127 \mathrm{I}_{\mathrm{n} 7}-0.127 \mathrm{I}_{\mathrm{n} 9}+25.151$ \\
\hline United Republic of Tanzania & $\mathrm{I}_{10}=0.369 \mathrm{I}_{\mathrm{n} 1}+0.075 \mathrm{I}_{\mathrm{n} 2}+0.075 \mathrm{I}_{\mathrm{n} 3}+0.085 \mathrm{I}_{\mathrm{n} 4}-0.086 \mathrm{I}_{\mathrm{n} 5}+0.093 \mathrm{I}_{\mathrm{n} 6}+0.112 \mathrm{I}_{\mathrm{n} 7}-0.127 \mathrm{I}_{\mathrm{n} 9}+19.028$ \\
\hline Zambia & $\mathrm{I}_{10}=0.005 \mathrm{I}_{\mathrm{n} 1}+0.121 \mathrm{I}_{\mathrm{n} 2}+0.124 \mathrm{I}_{\mathrm{n} 3}+0.138 \mathrm{I}_{\mathrm{n} 4}-0.134 \mathrm{I}_{\mathrm{n} 5}+0.224 \mathrm{I}_{\mathrm{n} 6}+0.126 \mathrm{I}_{\mathrm{n} 7}-0.129 \mathrm{I}_{\mathrm{n} 9}+26.305$ \\
\hline Zimbabwe & $\mathrm{I}_{10}=0.002 \mathrm{I}_{\mathrm{n} 1}+0.062 \mathrm{I}_{\mathrm{n} 2}+0.086 \mathrm{I}_{\mathrm{n} 3}+0.334 \mathrm{I}_{\mathrm{n} 4}-0.057 \mathrm{I}_{\mathrm{n} 5}+0.030 \mathrm{I}_{\mathrm{n} 6}+0.062 \mathrm{I}_{\mathrm{n} 7}-0.367 \mathrm{I}_{\mathrm{n} 9}+42.405$ \\
\hline
\end{tabular}

changes of the effective main indices on land use policy and agricultural water management have a wide range in Africa. Therefore, if we want to establish a relationship among the indices, each country should be considered separately.

\section{Estimation of land use policy index using the other main indices of agricultural water management}

The Tables 1 and 2 (using the Eqs. 8 and 9, respectively) show the functions estimated for the land use policy index in Africa.

A comparison between Tables 1 and 2 shows that the coefficients examined for the main indices are very similar in some cases and they are very different in other cases. It is due to nature of the Eqs. 8 and 9.

Prioritization of the main indices of land use policy and agricultural water management based on coefficients examined for each index

The Fig. 12 (based on the Eqs. 8 and 9) shows role of each index to estimate the land use policy index in Africa.

As was shown, role of the indices is similar or different if we use the Eq. 8 or 9. In addition, comparison of the countries shows distinguishable role of each index for that country. According to Fig. 12, in Sudano-Sahelian, the parameters that are more important include permanent crops to cultivated area (Burkina Faso, Chad, Eritrea, Mali, and Niger) and NRI (Djibouti and Sudan and South Sudan). It is consistent with Fig. $11 \mathrm{~b}$ and indicates that the Eqs. 8 and 9 are reliable. According to Fig. 12, in Gulf of Guinea, the most important parameter is permanent crops to cultivated area (Benin, Ghana, Nigeria, Sierra Leone, and Togo). It is consistent with Fig. 11c and indicates that the Eqs. 8 and 9 are reliable. According to Fig. 12, in Central Africa, the parameters that are more important include permanent crops to cultivated area (Cameroon, Central African Republic, and Sao Tome and Principe) and value added to GDP by agriculture (Angola, Congo, and Gabon. It is consistent with Fig. 11d and indicates that the Eqs. 8 and 9 are reliable. According to Fig. 12, in Eastern Africa, the most important parameter is permanent crops to cultivated area (with the exception of Ethiopia). It is consistent with Fig. 11e and indicates that the Eqs. 8 and 9 are reliable. According to Fig. 12, in Southern Africa, the most important parameter is value added to GDP by agriculture (Botswana, Lesotho, Namibia, and Zambia). It is consistent with Fig. 11f and indicates that the Eqs. 8 and 9 are reliable. The Fig. 13 could be applied to assess the effect of the main indices on the land use policy index in Africa based on the Eqs. 8 and 9 .

The Fig. 13 shows permanent crops to cultivated area, HDI, and value added to GDP by agriculture have highlighted effect on estimation of land use policy index. It is supported by the Figs. 11 and 12 and proves that the Eqs. 8 and 9 are reliable (Fig. 11 shows that status of these parameters is not suitable in Africa and based on the Fig. 12 they have the most impact on the poor irrigation in 
Table 2 Estimated functions using the second method (Eq. 10) for value of land use policy index in Africa (52 countries), this function is not calculable for Equatorial Guinea due to very poor irrigation

\begin{tabular}{|c|c|}
\hline Country & Suggested formula to estimate value of area equipped for irrigation to cultivated area (\%) \\
\hline Algeria & $\begin{array}{l}\mathrm{I}_{10}=0.061 \mathrm{I}_{\mathrm{n} 1}+0.117 \mathrm{I}_{\mathrm{n} 2}+0.075 \mathrm{I}_{\mathrm{n} 3}+0.116 \mathrm{I}_{\mathrm{n} 4}-0.108 \mathrm{I}_{\mathrm{n} 5}+0.060 \mathrm{I}_{\mathrm{n} 6}+0.080 \mathrm{I}_{\mathrm{n} 7}+0.049 \mathrm{I}_{\mathrm{n} 8}- \\
0.334 \mathrm{I}_{\mathrm{n} 9}+44.193\end{array}$ \\
\hline Angola & $\mathrm{I}_{10}=0.159 \mathrm{I}_{\mathrm{n} 1}+0.107 \mathrm{I}_{\mathrm{n} 2}+0.046 \mathrm{I}_{\mathrm{n} 3}+0.060 \mathrm{I}_{\mathrm{n} 4}-0.075 \mathrm{I}_{\mathrm{n} 5}+0.348 \mathrm{I}_{\mathrm{n} 6}+0.105 \mathrm{I}_{\mathrm{n} 7}-0.101 \mathrm{I}_{\mathrm{n} 9}+17.560$ \\
\hline Benin & $\begin{array}{l}\mathrm{I}_{10}=0.450 \mathrm{I}_{\mathrm{n} 1}+0.037 \mathrm{I}_{\mathrm{n} 2}+0.054 \mathrm{I}_{\mathrm{n} 3}+0.046 \mathrm{I}_{\mathrm{n} 4}-0.039 \mathrm{I}_{\mathrm{n} 5}+0.044 \mathrm{I}_{\mathrm{n} 6}+0.032 \mathrm{I}_{\mathrm{n} 7}+0.265 \mathrm{I}_{\mathrm{n} 8}- \\
0.033 \mathrm{I}_{\mathrm{n} 9}+7.234\end{array}$ \\
\hline Botswana & $\mathrm{I}_{10}=0.198 \mathrm{I}_{\mathrm{n} 1}+0.026 \mathrm{I}_{\mathrm{n} 2}+0.025 \mathrm{I}_{\mathrm{n} 3}+0.013 \mathrm{I}_{\mathrm{n} 4}-0.013 \mathrm{I}_{\mathrm{n} 5}+0.674 \mathrm{I}_{\mathrm{n} 6}+0.032 \mathrm{I}_{\mathrm{n} 7}-0.019 \mathrm{I}_{\mathrm{n} 9}+3.166$ \\
\hline Burkina Faso & $\mathrm{I}_{10}=0.741 \mathrm{I}_{\mathrm{n} 1}+0.024 \mathrm{I}_{\mathrm{n} 2}+0.020 \mathrm{I}_{\mathrm{n} 3}+0.049 \mathrm{I}_{\mathrm{n} 4}-0.028 \mathrm{I}_{\mathrm{n} 5}+0.034 \mathrm{I}_{\mathrm{n} 6}+0.062 \mathrm{I}_{\mathrm{n} 7}-0.043 \mathrm{I}_{\mathrm{n} 9}+7.121$ \\
\hline Burundi & $\mathrm{I}_{10}=0.193 \mathrm{I}_{\mathrm{n} 1}+0.065 \mathrm{I}_{\mathrm{n} 2}+0.067 \mathrm{I}_{\mathrm{n} 3}+0.158 \mathrm{I}_{\mathrm{n} 4}-0.111 \mathrm{I}_{\mathrm{n} 5}+0.109 \mathrm{I}_{\mathrm{n} 6}+0.157 \mathrm{I}_{\mathrm{n} 7}-0.140 \mathrm{I}_{\mathrm{n} 9}+25.063$ \\
\hline Cameroon & $\mathrm{I}_{10}=0.237 \mathrm{I}_{\mathrm{n} 1}+0.107 \mathrm{I}_{\mathrm{n} 2}+0.097 \mathrm{I}_{\mathrm{n} 3}+0.078 \mathrm{I}_{\mathrm{n} 4}-0.151 \mathrm{I}_{\mathrm{n} 5}+0.146 \mathrm{I}_{\mathrm{n} 6}+0.076 \mathrm{I}_{\mathrm{n} 7}-0.108 \mathrm{I}_{\mathrm{n} 9}+25.869$ \\
\hline Cape Verde & $\mathrm{I}_{10}=0.034 \mathrm{I}_{\mathrm{n} 1}+0.081 \mathrm{I}_{\mathrm{n} 2}+0.041 \mathrm{I}_{\mathrm{n} 3}+0.671 \mathrm{I}_{\mathrm{n} 4}+0.042 \mathrm{I}_{\mathrm{n} 6}+0.131 \mathrm{I}_{\mathrm{n} 7}$ \\
\hline Central African Republic & $\mathrm{I}_{10}=0.617 \mathrm{I}_{\mathrm{n} 1}+0.046 \mathrm{I}_{\mathrm{n} 2}+0.047 \mathrm{I}_{\mathrm{n} 3}+0.072 \mathrm{I}_{\mathrm{n} 4}-0.066 \mathrm{I}_{\mathrm{n} 5}+0.032 \mathrm{I}_{\mathrm{n} 6}+0.056 \mathrm{I}_{\mathrm{n} 7}-0.064 \mathrm{I}_{\mathrm{n} 9}+13.023$ \\
\hline Chad & $\mathrm{I}_{10}=0.433 \mathrm{I}_{\mathrm{n} 1}+0.044 \mathrm{I}_{\mathrm{n} 2}+0.051 \mathrm{I}_{\mathrm{n} 3}+0.093 \mathrm{I}_{\mathrm{n} 4}-0.048 \mathrm{I}_{\mathrm{n} 5}+0.201 \mathrm{I}_{\mathrm{n} 6}+0.073 \mathrm{I}_{\mathrm{n} 7}-0.058 \mathrm{I}_{\mathrm{n} 9}+10.593$ \\
\hline Comoros & $\mathrm{I}_{10}=0.080 \mathrm{I}_{\mathrm{n} 1}+0.054 \mathrm{I}_{\mathrm{n} 2}+0.054 \mathrm{I}_{\mathrm{n} 3}+0.076 \mathrm{I}_{\mathrm{n} 4}-0.476 \mathrm{I}_{\mathrm{n} 5}+0.050 \mathrm{I}_{\mathrm{n} 6}+0.210 \mathrm{I}_{\mathrm{n} 7}+47.577$ \\
\hline Congo & $\mathrm{I}_{10}=0.195 \mathrm{I}_{\mathrm{n} 1}+0.059 \mathrm{I}_{\mathrm{n} 2}+0.074 \mathrm{I}_{\mathrm{n} 3}+0.038 \mathrm{I}_{\mathrm{n} 4}-0.071 \mathrm{I}_{\mathrm{n} 5}+0.447 \mathrm{I}_{\mathrm{n} 6}+0.049 \mathrm{I}_{\mathrm{n} 7}-0.067 \mathrm{I}_{\mathrm{n} 9}+13.809$ \\
\hline Côte d'Ivoire & $\mathrm{I}_{10}=0.088 \mathrm{I}_{\mathrm{n} 1}+0.123 \mathrm{I}_{\mathrm{n} 2}+0.178 \mathrm{I}_{\mathrm{n} 3}+0.126 \mathrm{I}_{\mathrm{n} 4}-0.126 \mathrm{I}_{\mathrm{n} 5}+0.165 \mathrm{I}_{\mathrm{n} 6}+0.091 \mathrm{I}_{\mathrm{n} 7}-0.103 \mathrm{I}_{\mathrm{n} 9}+22.993$ \\
\hline $\begin{array}{l}\text { Democratic Republic of the } \\
\text { Congo }\end{array}$ & $\begin{array}{l}\mathrm{I}_{10}=0.088 \mathrm{I}_{\mathrm{n} 1}+0.014 \mathrm{I}_{\mathrm{n} 2}+0.016 \mathrm{I}_{\mathrm{n} 3}+0.026 \mathrm{I}_{\mathrm{n} 4}-0.026 \mathrm{I}_{\mathrm{n} 5}+0.012 \mathrm{I}_{\mathrm{n} 6}+0.023 \mathrm{I}_{\mathrm{n} 7}+0.766 \mathrm{I}_{\mathrm{n} 8}- \\
0.029 \mathrm{I}_{\mathrm{n} 9}+5.478\end{array}$ \\
\hline Djibouti & $\mathrm{I}_{10}=0.035 \mathrm{I}_{\mathrm{n} 2}+0.129 \mathrm{I}_{\mathrm{n} 3}+0.058 \mathrm{I}_{\mathrm{n} 4}-0.616 \mathrm{I}_{\mathrm{n} 5}+0.028 \mathrm{I}_{\mathrm{n} 6}+0.046 \mathrm{I}_{\mathrm{n} 7}-0.087 \mathrm{I}_{\mathrm{n} 9}+70.333$ \\
\hline Egypt & $\begin{array}{l}\mathrm{I}_{10}=0.001 \mathrm{I}_{\mathrm{n} 1}+0.002 \mathrm{I}_{\mathrm{n} 2}+0.001 \mathrm{I}_{\mathrm{n} 3}+0.003 \mathrm{I}_{\mathrm{n} 4}-0.014 \mathrm{I}_{\mathrm{n} 5}+0.001 \mathrm{I}_{\mathrm{n} 6}+0.001 \mathrm{I}_{\mathrm{n} 7}+0.976 \mathrm{I}_{\mathrm{n} 8}- \\
\quad 0.002 \mathrm{I}_{\mathrm{n} 9}+1.579\end{array}$ \\
\hline Eritrea & $\mathrm{I}_{10}=0.339 \mathrm{I}_{\mathrm{n} 1}+0.044 \mathrm{I}_{\mathrm{n} 2}+0.049 \mathrm{I}_{\mathrm{n} 3}+0.103 \mathrm{I}_{\mathrm{n} 4}-0.045 \mathrm{I}_{\mathrm{n} 5}+0.227 \mathrm{I}_{\mathrm{n} 6}+0.124 \mathrm{I}_{\mathrm{n} 7}-0.068 \mathrm{I}_{\mathrm{n} 9}+11.283$ \\
\hline Ethiopia & $\mathrm{I}_{10}=0.082 \mathrm{I}_{\mathrm{n} 1}+0.025 \mathrm{I}_{\mathrm{n} 2}+0.029 \mathrm{I}_{\mathrm{n} 3}+0.077 \mathrm{I}_{\mathrm{n} 4}-0.054 \mathrm{I}_{\mathrm{n} 5}+0.030 \mathrm{I}_{\mathrm{n} 6}+0.536 \mathrm{I}_{\mathrm{n} 7}-0.167 \mathrm{I}_{\mathrm{n} 9}+22.111$ \\
\hline Gabon & $\mathrm{I}_{10}=0.007 \mathrm{I}_{\mathrm{n} 1}+0.031 \mathrm{I}_{\mathrm{n} 2}+0.013 \mathrm{I}_{\mathrm{n} 3}+0.003 \mathrm{I}_{\mathrm{n} 4}-0.013 \mathrm{I}_{\mathrm{n} 5}+0.914 \mathrm{I}_{\mathrm{n} 6}+0.007 \mathrm{I}_{\mathrm{n} 7}-0.012 \mathrm{I}_{\mathrm{n} 9}+2.447$ \\
\hline Gambia & $\mathrm{I}_{10}=0.244 \mathrm{I}_{\mathrm{n} 1}+0.067 \mathrm{I}_{\mathrm{n} 2}+0.033 \mathrm{I}_{\mathrm{n} 3}+0.054 \mathrm{I}_{\mathrm{n} 4}-0.036 \mathrm{I}_{\mathrm{n} 5}+0.106 \mathrm{I}_{\mathrm{n} 6}+0.378 \mathrm{I}_{\mathrm{n} 7}-0.083 \mathrm{I}_{\mathrm{n} 9}+11.857$ \\
\hline Ghana & $\mathrm{I}_{10}=0.159 \mathrm{I}_{\mathrm{n} 1}+0.131 \mathrm{I}_{\mathrm{n} 2}+0.118 \mathrm{I}_{\mathrm{n} 3}+0.099 \mathrm{I}_{\mathrm{n} 4}-0.124 \mathrm{I}_{\mathrm{n} 5}+0.159 \mathrm{I}_{\mathrm{n} 6}+0.101 \mathrm{I}_{\mathrm{n} 7}-0.109 \mathrm{I}_{\mathrm{n} 9}+23.317$ \\
\hline Guinea & $\begin{array}{l}\mathrm{I}_{10}=0.154 \mathrm{I}_{\mathrm{n} 1}+0.040 \mathrm{I}_{\mathrm{n} 2}+0.033 \mathrm{I}_{\mathrm{n} 3}+0.070 \mathrm{I}_{\mathrm{n} 4}-0.091 \mathrm{I}_{\mathrm{n} 5}+0.082 \mathrm{I}_{\mathrm{n} 6}+0.036 \mathrm{I}_{\mathrm{n} 7}+0.443 \mathrm{I}_{\mathrm{n} 8}- \\
0.051 \mathrm{I}_{\mathrm{n} 9}+14.188\end{array}$ \\
\hline Guinea-Bissau & $\mathrm{I}_{10}=0.154 \mathrm{I}_{\mathrm{n} 1}+0.095 \mathrm{I}_{\mathrm{n} 2}+0.084 \mathrm{I}_{\mathrm{n} 3}+0.214 \mathrm{I}_{\mathrm{n} 4}-0.170 \mathrm{I}_{\mathrm{n} 5}+0.072 \mathrm{I}_{\mathrm{n} 6}+0.094 \mathrm{I}_{\mathrm{n} 7}-0.115 \mathrm{I}_{\mathrm{n} 9}+28.549$ \\
\hline Kenya & $\begin{array}{l}\mathrm{I}_{10}=0.409 \mathrm{I}_{\mathrm{n} 1}+0.029 \mathrm{I}_{\mathrm{n} 2}+0.034 \mathrm{I}_{\mathrm{n} 3}+0.043 \mathrm{I}_{\mathrm{n} 4}-0.043 \mathrm{I}_{\mathrm{n} 5}+0.062 \mathrm{I}_{\mathrm{n} 6}+0.174 \mathrm{I}_{\mathrm{n} 7}+0.117 \mathrm{I}_{\mathrm{n} 8}- \\
0.088 \mathrm{I}_{\mathrm{n} 9}+13.076\end{array}$ \\
\hline Lesotho & $\mathrm{I}_{10}=0.286 \mathrm{I}_{\mathrm{n} 1}+0.028 \mathrm{I}_{\mathrm{n} 2}+0.061 \mathrm{I}_{\mathrm{n} 3}+0.042 \mathrm{I}_{\mathrm{n} 4}-0.033 \mathrm{I}_{\mathrm{n} 5}+0.411 \mathrm{I}_{\mathrm{n} 6}+0.086 \mathrm{I}_{\mathrm{n} 7}-0.053 \mathrm{I}_{\mathrm{n} 9}+8.574$ \\
\hline Liberia & $\mathrm{I}_{10}=0.081 \mathrm{I}_{\mathrm{n} 1}+0.049 \mathrm{I}_{\mathrm{n} 2}+0.042 \mathrm{I}_{\mathrm{n} 3}+0.059 \mathrm{I}_{\mathrm{n} 4}-0.557 \mathrm{I}_{\mathrm{n} 5}+0.030 \mathrm{I}_{\mathrm{n} 6}+0.052 \mathrm{I}_{\mathrm{n} 7}-0.129 \mathrm{I}_{\mathrm{n} 9}+68.684$ \\
\hline Libya & $\begin{array}{l}\mathrm{I}_{10}=0.037 \mathrm{I}_{\mathrm{n} 1}+0.041 \mathrm{I}_{\mathrm{n} 2}+0.028 \mathrm{I}_{\mathrm{n} 3}+0.088 \mathrm{I}_{\mathrm{n} 4}-0.092 \mathrm{I}_{\mathrm{n} 5}+0.029 \mathrm{I}_{\mathrm{n} 6}+0.069 \mathrm{I}_{\mathrm{n} 7}+0.027 \mathrm{I}_{\mathrm{n} 8}- \\
0.588 \mathrm{I}_{\mathrm{n} 9}+68.037\end{array}$ \\
\hline Madagascar & $\mathrm{I}_{10}=0.008 \mathrm{I}_{\mathrm{n} 1}+0.307 \mathrm{I}_{\mathrm{n} 2}+0.589 \mathrm{I}_{\mathrm{n} 3}+0.028 \mathrm{I}_{\mathrm{n} 4}-0.013 \mathrm{I}_{\mathrm{n} 5}+0.018 \mathrm{I}_{\mathrm{n} 6}+0.022 \mathrm{I}_{\mathrm{n} 7}-0.014 \mathrm{I}_{\mathrm{n} 9}+2.698$ \\
\hline Malawi & $\mathrm{I}_{10}=0.189 \mathrm{I}_{\mathrm{n} 1}+0.055 \mathrm{I}_{\mathrm{n} 2}+0.059 \mathrm{I}_{\mathrm{n} 3}+0.128 \mathrm{I}_{\mathrm{n} 4}-0.113 \mathrm{I}_{\mathrm{n} 5}+0.124 \mathrm{I}_{\mathrm{n} 6}+0.172 \mathrm{I}_{\mathrm{n} 7}-0.161 \mathrm{I}_{\mathrm{n} 9}+27.324$ \\
\hline Mali & $\mathrm{I}_{10}=0.266 \mathrm{I}_{\mathrm{n} 1}+0.090 \mathrm{I}_{\mathrm{n} 2}+0.076 \mathrm{I}_{\mathrm{n} 3}+0.200 \mathrm{I}_{\mathrm{n} 4}-0.080 \mathrm{I}_{\mathrm{n} 5}+0.104 \mathrm{I}_{\mathrm{n} 6}+0.100 \mathrm{I}_{\mathrm{n} 7}-0.084 \mathrm{I}_{\mathrm{n} 9}+16.451$ \\
\hline Mauritania & $\begin{array}{l}\mathrm{I}_{10}=0.004 \mathrm{I}_{\mathrm{n} 1}+0.019 \mathrm{I}_{\mathrm{n} 2}+0.885 \mathrm{I}_{\mathrm{n} 3}+0.064 \mathrm{I}_{\mathrm{n} 4}-0.005 \mathrm{I}_{\mathrm{n} 5}+0.008 \mathrm{I}_{\mathrm{n} 6}+0.006 \mathrm{I}_{\mathrm{n} 7}+0.004 \mathrm{I}_{\mathrm{n} 8}- \\
\quad 0.005 \mathrm{I}_{\mathrm{n} 9}+0.991\end{array}$ \\
\hline Mauritius & $\mathrm{I}_{10}=0.062 \mathrm{I}_{\mathrm{n} 1}+0.408 \mathrm{I}_{\mathrm{n} 2}+0.065 \mathrm{I}_{\mathrm{n} 3}+0.284 \mathrm{I}_{\mathrm{n} 4}+0.063 \mathrm{I}_{\mathrm{n} 6}+0.118 \mathrm{I}_{\mathrm{n} 7}$ \\
\hline Morocco & $\begin{array}{l}\mathrm{I}_{10}=0.034 \mathrm{I}_{\mathrm{n} 1}+0.064 \mathrm{I}_{\mathrm{n} 2}+0.041 \mathrm{I}_{\mathrm{n} 3}+0.279 \mathrm{I}_{\mathrm{n} 4}-0.310 \mathrm{I}_{\mathrm{n} 5}+0.041 \mathrm{I}_{\mathrm{n} 6}+0.059 \mathrm{I}_{\mathrm{n} 7}+0.031 \mathrm{I}_{\mathrm{n} 8}- \\
0.141 \mathrm{I}_{\mathrm{n} 9}+45.081\end{array}$ \\
\hline Mozambique & $\begin{array}{l}\mathrm{I}_{10}=0.126 \mathrm{I}_{\mathrm{n} 1}+0.060 \mathrm{I}_{\mathrm{n} 2}+0.042 \mathrm{I}_{\mathrm{n} 3}+0.168 \mathrm{I}_{\mathrm{n} 4}-0.073 \mathrm{I}_{\mathrm{n} 5}+0.084 \mathrm{I}_{\mathrm{n} 6}+0.207 \mathrm{I}_{\mathrm{n} 7}+0.103 \mathrm{I}_{\mathrm{n} 8}- \\
0.137 \mathrm{I}_{\mathrm{n} 9}+21.013\end{array}$ \\
\hline Namibia & $\begin{array}{l}\mathrm{I}_{10}=0.201 \mathrm{I}_{\mathrm{n} 1}+0.026 \mathrm{I}_{\mathrm{n} 2}+0.060 \mathrm{I}_{\mathrm{n} 3}+0.024 \mathrm{I}_{\mathrm{n} 4}-0.020 \mathrm{I}_{\mathrm{n} 5}+0.437 \mathrm{I}_{\mathrm{n} 6}+0.031 \mathrm{I}_{\mathrm{n} 7}+0.177 \mathrm{I}_{\mathrm{n} 8}- \\
\quad 0.024 \mathrm{I}_{\mathrm{n} 9}+4.409\end{array}$ \\
\hline Niger & $\mathrm{I}_{10}=0.961 \mathrm{I}_{\mathrm{n} 1}+0.004 \mathrm{I}_{\mathrm{n} 2}+0.005 \mathrm{I}_{\mathrm{n} 3}+0.011 \mathrm{I}_{\mathrm{n} 4}-0.005 \mathrm{I}_{\mathrm{n} 5}+0.006 \mathrm{I}_{\mathrm{n} 6}+0.004 \mathrm{I}_{\mathrm{n} 7}-0.004 \mathrm{I}_{\mathrm{n} 9}+0.879$ \\
\hline Nigeria & $\mathrm{I}_{10}=0.548 \mathrm{I}_{\mathrm{n} 1}+0.045 \mathrm{I}_{\mathrm{n} 2}+0.110 \mathrm{I}_{\mathrm{n} 3}+0.042 \mathrm{I}_{\mathrm{n} 4}-0.052 \mathrm{I}_{\mathrm{n} 5}+0.047 \mathrm{I}_{\mathrm{n} 6}+0.079 \mathrm{I}_{\mathrm{n} 7}-0.078 \mathrm{I}_{\mathrm{n} 9}+12.931$ \\
\hline Rwanda & $\mathrm{I}_{10}=0.311 \mathrm{I}_{\mathrm{n} 1}+0.062 \mathrm{I}_{\mathrm{n} 2}+0.058 \mathrm{I}_{\mathrm{n} 3}+0.107 \mathrm{I}_{\mathrm{n} 4}-0.098 \mathrm{I}_{\mathrm{n} 5}+0.102 \mathrm{I}_{\mathrm{n} 6}+0.137 \mathrm{I}_{\mathrm{n} 7}-0.125 \mathrm{I}_{\mathrm{n} 9}+22.261$ \\
\hline Sao Tome and Principe & $\mathrm{I}_{10}=0.189 \mathrm{I}_{\mathrm{n} 1}+0.107 \mathrm{I}_{\mathrm{n} 2}+0.231 \mathrm{I}_{\mathrm{n} 3}+0.287 \mathrm{I}_{\mathrm{n} 4}+0.077 \mathrm{I}_{\mathrm{n} 6}+0.109 \mathrm{I}_{\mathrm{n} 7}$ \\
\hline
\end{tabular}


Table 2 continued

\begin{tabular}{|c|c|}
\hline Country & Suggested formula to estimate value of area equipped for irrigation to cultivated area (\%) \\
\hline Senegal & $\begin{array}{l}\mathrm{I}_{10}=0.087 \mathrm{I}_{\mathrm{n} 1}+0.084 \mathrm{I}_{\mathrm{n} 2}+0.061 \mathrm{I}_{\mathrm{n} 3}+0.103 \mathrm{I}_{\mathrm{n} 4}-0.059 \mathrm{I}_{\mathrm{n} 5}+0.438 \mathrm{I}_{\mathrm{n} 6}+0.040 \mathrm{I}_{\mathrm{n} 7}+0.087 \mathrm{I}_{\mathrm{n} 8}- \\
0.040 \mathrm{I}_{\mathrm{n} 9}+9.970\end{array}$ \\
\hline Seychelles & $\mathrm{I}_{10}=0.400 \mathrm{I}_{\mathrm{n} 1}+0.057 \mathrm{I}_{\mathrm{n} 2}+0.301 \mathrm{I}_{\mathrm{n} 3}+0.161 \mathrm{I}_{\mathrm{n} 4}+0.026 \mathrm{I}_{\mathrm{n} 6}+0.031 \mathrm{I}_{\mathrm{n} 7}+0.025 \mathrm{I}_{\mathrm{n} 8}$ \\
\hline Sierra Leone & $\mathrm{I}_{10}=0.372 \mathrm{I}_{\mathrm{n} 1}+0.065 \mathrm{I}_{\mathrm{n} 2}+0.069 \mathrm{I}_{\mathrm{n} 3}+0.101 \mathrm{I}_{\mathrm{n} 4}+0.009 \mathrm{I}_{\mathrm{n} 6}+0.082 \mathrm{I}_{\mathrm{n} 7}-0.254 \mathrm{I}_{\mathrm{n} 9}+25.390$ \\
\hline Somalia & $\mathrm{I}_{10}=0.0004 \mathrm{I}_{\mathrm{n} 1}+0.001 \mathrm{I}_{\mathrm{n} 2}+0.001 \mathrm{I}_{\mathrm{n} 3}-0.0005 \mathrm{I}_{\mathrm{n} 5}+0.997 \mathrm{I}_{\mathrm{n} 7}-0.001 \mathrm{I}_{\mathrm{n} 9}+0.140$ \\
\hline South Africa & $\begin{array}{l}\mathrm{I}_{10}=0.037 \mathrm{I}_{\mathrm{n} 1}+0.094 \mathrm{I}_{\mathrm{n} 2}+0.038 \mathrm{I}_{\mathrm{n} 3}+0.212 \mathrm{I}_{\mathrm{n} 4}-0.204 \mathrm{I}_{\mathrm{n} 5}+0.037 \mathrm{I}_{\mathrm{n} 6}+0.091 \mathrm{I}_{\mathrm{n} 7}+0.035 \mathrm{I}_{\mathrm{n} 8}- \\
0.252 \mathrm{I}_{\mathrm{n} 9}+45.619\end{array}$ \\
\hline Sudan and South Sudan & $\begin{array}{l}\mathrm{I}_{10}=0.059 \mathrm{I}_{\mathrm{n} 1}+0.167 \mathrm{I}_{\mathrm{n} 2}+0.126 \mathrm{I}_{\mathrm{n} 3}+0.117 \mathrm{I}_{\mathrm{n} 4}-0.190 \mathrm{I}_{\mathrm{n} 5}+0.100 \mathrm{I}_{\mathrm{n} 6}+0.079 \mathrm{I}_{\mathrm{n} 7}+0.061 \mathrm{I}_{\mathrm{n} 8}- \\
0.101 \mathrm{I}_{\mathrm{n} 9}+29.102\end{array}$ \\
\hline Swaziland & $\mathrm{I}_{10}=0.017 \mathrm{I}_{\mathrm{n} 1}+0.706 \mathrm{I}_{\mathrm{n} 2}+0.023 \mathrm{I}_{\mathrm{n} 3}+0.064 \mathrm{I}_{\mathrm{n} 4}-0.107 \mathrm{I}_{\mathrm{n} 5}+0.018 \mathrm{I}_{\mathrm{n} 6}+0.027 \mathrm{I}_{\mathrm{n} 7}-0.040 \mathrm{I}_{\mathrm{n} 9}+14.605$ \\
\hline Togo & $\mathrm{I}_{10}=0.507 \mathrm{I}_{\mathrm{n} 1}+0.070 \mathrm{I}_{\mathrm{n} 2}+0.076 \mathrm{I}_{\mathrm{n} 3}+0.077 \mathrm{I}_{\mathrm{n} 4}-0.075 \mathrm{I}_{\mathrm{n} 5}+0.078 \mathrm{I}_{\mathrm{n} 6}+0.055 \mathrm{I}_{\mathrm{n} 7}-0.061 \mathrm{I}_{\mathrm{n} 9}+13.639$ \\
\hline Tunisia & $\begin{array}{l}\mathrm{I}_{10}=0.091 \mathrm{I}_{\mathrm{n} 1}+0.051 \mathrm{I}_{\mathrm{n} 2}+0.038 \mathrm{I}_{\mathrm{n} 3}+0.284 \mathrm{I}_{\mathrm{n} 4}-0.333 \mathrm{I}_{\mathrm{n} 5}+0.034 \mathrm{I}_{\mathrm{n} 6}+0.046 \mathrm{I}_{\mathrm{n} 7}+0.030 \mathrm{I}_{\mathrm{n} 8}- \\
0.093 \mathrm{I}_{\mathrm{n} 9}+42.579\end{array}$ \\
\hline Uganda & $\mathrm{I}_{10}=0.176 \mathrm{I}_{\mathrm{n} 1}+0.053 \mathrm{I}_{\mathrm{n} 2}+0.063 \mathrm{I}_{\mathrm{n} 3}+0.091 \mathrm{I}_{\mathrm{n} 4}-0.110 \mathrm{I}_{\mathrm{n} 5}+0.127 \mathrm{I}_{\mathrm{n} 6}+0.194 \mathrm{I}_{\mathrm{n} 7}-0.186 \mathrm{I}_{\mathrm{n} 9}+29.668$ \\
\hline United Republic of Tanzania & $\mathrm{I}_{10}=0.660 \mathrm{I}_{\mathrm{n} 1}+0.026 \mathrm{I}_{\mathrm{n} 2}+0.026 \mathrm{I}_{\mathrm{n} 3}+0.040 \mathrm{I}_{\mathrm{n} 4}-0.043 \mathrm{I}_{\mathrm{n} 5}+0.054 \mathrm{I}_{\mathrm{n} 6}+0.083 \mathrm{I}_{\mathrm{n} 7}-0.070 \mathrm{I}_{\mathrm{n} 9}+11.251$ \\
\hline Zambia & $\mathrm{I}_{10}=0.185 \mathrm{I}_{\mathrm{n} 1}+0.073 \mathrm{I}_{\mathrm{n} 2}+0.079 \mathrm{I}_{\mathrm{n} 3}+0.107 \mathrm{I}_{\mathrm{n} 4}-0.100 \mathrm{I}_{\mathrm{n} 5}+0.283 \mathrm{I}_{\mathrm{n} 6}+0.084 \mathrm{I}_{\mathrm{n} 7}-0.090 \mathrm{I}_{\mathrm{n} 9}+18.956$ \\
\hline Zimbabwe & $\mathrm{I}_{10}=0.023 \mathrm{I}_{\mathrm{n} 1}+0.043 \mathrm{I}_{\mathrm{n} 2}+0.069 \mathrm{I}_{\mathrm{n} 3}+0.327 \mathrm{I}_{\mathrm{n} 4}-0.039 \mathrm{I}_{\mathrm{n} 5}+0.052 \mathrm{I}_{\mathrm{n} 6}+0.086 \mathrm{I}_{\mathrm{n} 7}-0.361 \mathrm{I}_{\mathrm{n} 9}+39.970$ \\
\hline
\end{tabular}

Africa). As shown in the Fig. 13a, role of the all indices is close together. It evidences that the all selected parameters (the main indices) are important and reasonable. According to Fig. 13b, c, d, rural population to total population, total economically active population in agriculture to total economically active population, and difference between NRI and irrigation water requirement have the minimum effect (with the exception of percentage of total cultivated area drained due to very poor drainage in Africa) on estimation of land use policy index. It is also supported by the Figs. 11 and 12 and proves that the Eqs. 8 and 9 are reliable (the Fig. 11 shows that status of these parameters is suitable in Africa and they have the least impact on poor irrigation in Africa based on the Fig. 12, it means that rural population, labor force, and lack of appropriate performance in rainfed agriculture because of drastic water deficit, could not encourage governments and/or farmers to apply irrigation systems). Although ability of the Eqs. 8 and 9 was proved according to the text, accuracy of them was determined using the Eqs. 12-14.

Calculation of the error for functions suggested for estimating land use policy index

The Table 3 shows calculated errors for functions suggested (the Tables 1, 2) using the Eqs. 12-14.

According to Table 3, accuracy of the Eq. 8 is more than the Eq. 9. The values of the mean relative error are $<20 \%$ (with the exception of Cape Verde, Comoros, and Libya). Equations. 8 and 9 must be used for Cape Verde, Mauritius, Sao Tome and Principe, and Somalia (Tables 1,
2) warily because of its error. However, we can update the formulas of the Tables 1 and 2 using Eqs. 8 and 9, and based on new data (or only $f_{\mathrm{c}}$ ) at the end of any water year. In the next step, general status of the countries for land use policy and agricultural water management has been studied using the Eqs. 15 and 16.

\section{General conditions of the countries for land use policy and agricultural water management based on the main indices in 2011}

The Table 4 presents general conditions of the countries for land use policy and agricultural water management based on the the Eqs. 15 and 16.

According to Table 4, conditions of land use policy and agricultural water management are suitable for Djibouti, Egypt, Madagascar, and fair for Cape Verde, Equatorial Guinea, Ethiopia, Mauritania, and Mauritius. However, conditions of land use policy and agricultural water management are unsuitable for the other countries in Africa. As shown in Table 4, conditions of the countries are different due to nature of Eqs. 15 and 16; the desirability of condition for agricultural water management is $<40 \%$ for Northern Africa (with the exception of Egypt $51 \%$ ) and Sudano-Sahelian Africa (with the exception of Burkina Faso $43 \%$ ) and it is $<50 \%$ for Gulf of Guinea (with the exception of Liberia $52 \%$ and Sierra Leone $50 \%$ ), Eastern Africa (with the exception of Uganda $50 \%$ ), Southern Africa and Central Africa. While according to the Eq. 16, the desirability of condition for agricultural water 


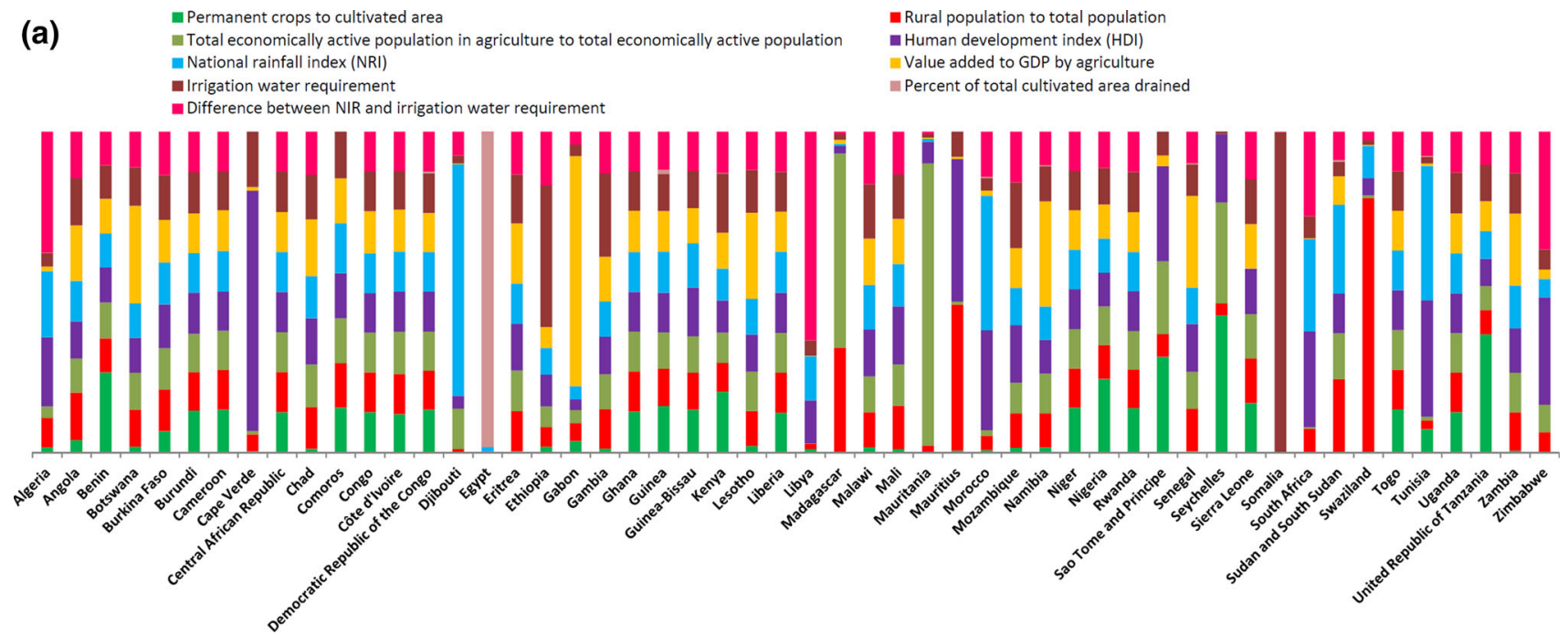

(b)

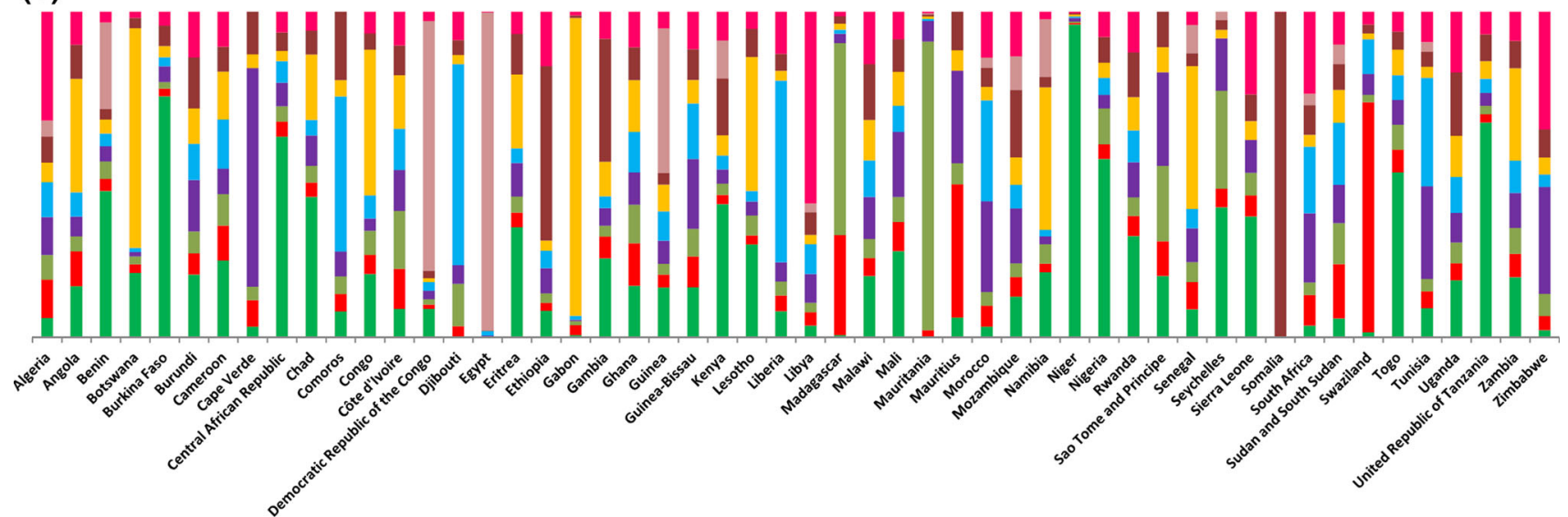

Fig. 12 Role of each index to estimate the land use policy index based on Eq. 8 (a) and Eq. 9 (b) in Africa (52 countries), the prioritization is not calculable for Equatorial Guinea due to very poor irrigation

management is $<30 \%$ for Northern Africa (with the exception of Egypt $99 \%$ ), Gulf of Guinea, Central Africa (with the exception of Sao Tome and Principe $43 \%$ ), Eastern Africa (with the exception of Ethiopia $30 \%$ ), and Southern Africa (with the exception of Swaziland $49 \%$ ). Egypt is the best country for land use policy and agricultural water management because its desirability of condition $(99 \%)$ is more than all the countries in Africa. In the other words, land use policy and agricultural water management in Egypt (Kheira 2009a) is more comfortable than the other countries. Although the functions determined to estimate land use policy index were tested for all years (that data was available for them) and while data was not available in 2011, data of previous years was used, but other mentioned contents were for 2011. Since, a thorough study is required to assess trend of land use policy and agricultural water management in the past half of century.
Land use policy and agricultural water management based on the main indices for Africa in the previous half of century

The Fig. 14 shows variations of the main indices for Africa in the previous half of century.

According to Fig. 14, variations of permanent crops to cultivated area and percentage of total cultivated area drained were not significant and the value of NRI was variable during the previous half of century due to many different factors such as greenhouse gases (Sauerborn et al. 1999), global warming (Michaels 1990), climate change (Muzik 2002), etc. However, trend of rural population to total population, total economically active population in agriculture to total economically active population, and value added to GDP by agriculture were declining. In the first two decades (1962-1982), the difference between rural development and labor force was significant hence; value 

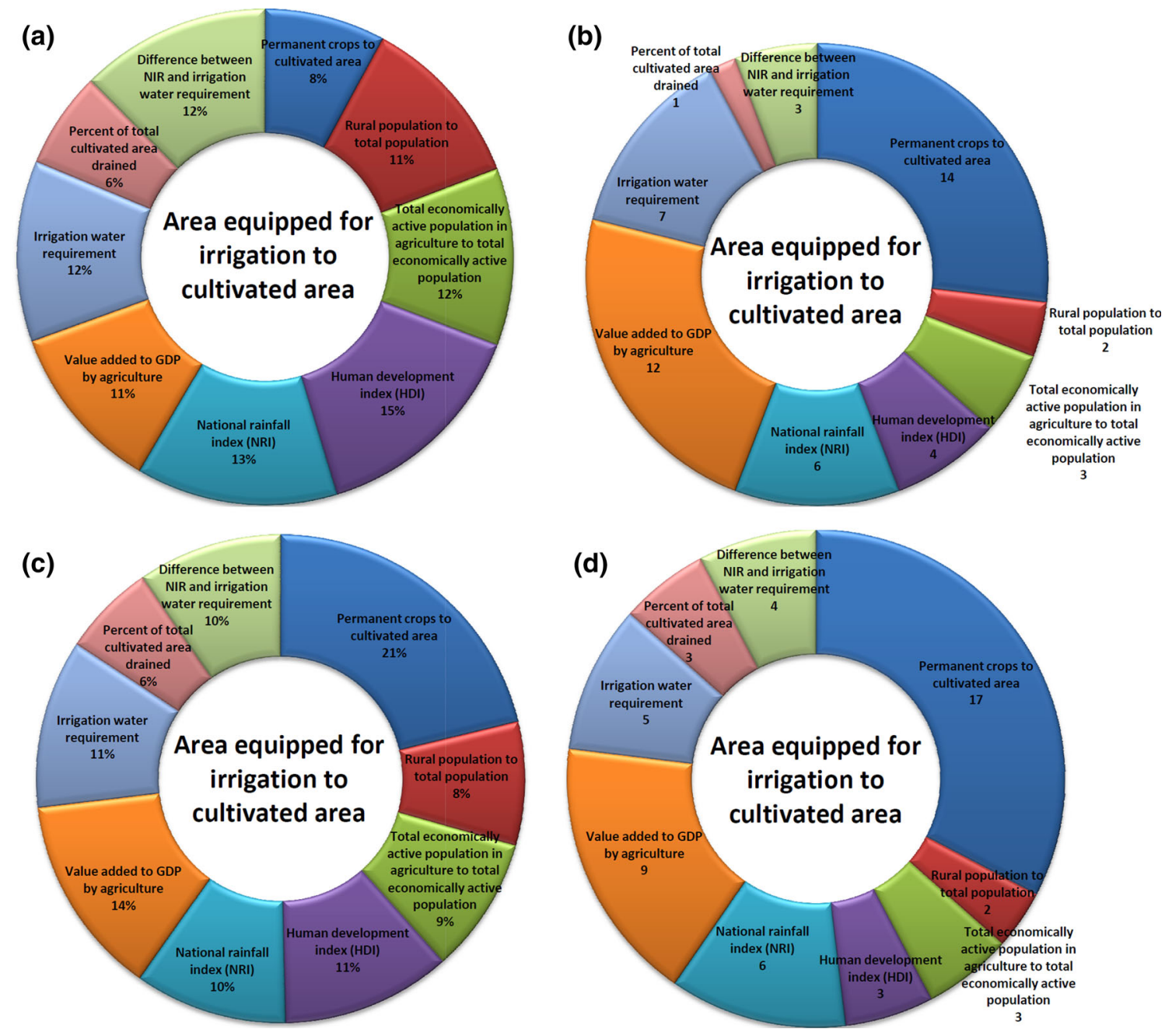

Fig. 13 Effect of the main indices on area equipped in Africa (52 countries according to available data); a and c, average of coefficients for each index in the Tables 1 and 2 respectively, $b$ and $d$, number of

added to GDP by agriculture was decreased. From 1982 to 1997, values of rural population to total population and total economically active population in agriculture to total economically active population were close together hence; value added to GDP by agriculture was almost constant. From 1997 to 2011, the difference between rural development and labor force was declining again hence; value added to GDP by agriculture was also decreased. Thus, slope of land use policy index was less than slope of HDI and water deficit (difference between NRI and irrigation water requirement) did not encourage governments and/or farmers to increase irrigation systems. It is a big warning for developing countries (Hussain 2007). Although mechanization and use of new technologies have an important role in enhancement of agricultural knowledge and increasing productivity (Kirpich et al. 1999), labour force cases that each index has been introduced as main factor to estimate land use policy index (maximum coefficient in each formula) based on Eqs. 8 and 9 respectively

has a vital and irreplaceable role in agricultural scheduling and macroeconomic perspectives (Kuper et al. 2009). However, other parameters as well as probable disadvantages of irrigation systems (the sub-main indices) are also affective on agricultural water management that their comprehensive study is not possible due to limited information in Africa.

\section{Evaluation of the sub-main indices of land use policy and agricultural water management for Africa}

The Fig. 15 shows variations of the sub-main indices of land use policy and agricultural water management in Africa. 
Table 3 Calculated errors for suggested functions (Tables 1,2), the errors $<10 \%$ show a suitable status, the errors between 10 and $20 \%$ show a fair status, and the errors more than $20 \%$ show a difficult status to apply the Eqs. 8 and 9 (the first and the second formulas, respectively)

\begin{tabular}{|c|c|c|c|c|c|c|}
\hline \multirow[t]{2}{*}{ Country } & \multicolumn{3}{|c|}{ Relative error in the first formula (\%) } & \multicolumn{3}{|c|}{ Relative error in the second formula $(\%)$} \\
\hline & Minimum & Mean & Maximum & Minimum & Mean & Maximum \\
\hline Algeria & 3.0 & 16.1 & 26.4 & 3.6 & 15.0 & 25.8 \\
\hline Angola & 5.2 & 9.5 & 17.9 & 4.5 & 9.1 & 16.7 \\
\hline Benin & 5.0 & 12.9 & 22.3 & 4.0 & 12.7 & 20.3 \\
\hline Botswana & 5.5 & 9.8 & 19.3 & 0.7 & 5.3 & 10.7 \\
\hline Burkina Faso & 6.7 & 13.2 & 21.5 & 3.1 & 8.2 & 13.8 \\
\hline Burundi & 6.5 & 11.1 & 20.2 & 2.4 & 5.6 & 10.4 \\
\hline Cameroon & 5.6 & 10.9 & 20.4 & 2.4 & 8.1 & 13.2 \\
\hline Cape Verde & 8.5 & 21.2 & 35.2 & 9.8 & 20.4 & 25.2 \\
\hline Central African Republic & 0.8 & 13.3 & 22.9 & 0.9 & 11.7 & 21.3 \\
\hline Chad & 2.1 & 10.5 & 16.3 & 3.0 & 11.2 & 14.5 \\
\hline Comoros & 10.0 & 20.9 & 37.7 & 5.0 & 19.5 & 37.1 \\
\hline Congo & 4.4 & 12.8 & 19.9 & 2.1 & 13.3 & 16.4 \\
\hline Côte d'Ivoire & 6.7 & 13.5 & 20.9 & 6.5 & 11.8 & 12.6 \\
\hline Democratic Republic of the Congo & 3.2 & 5.8 & 11.5 & 3.8 & 5.9 & 11.8 \\
\hline Djibouti & 1.8 & 12.8 & 17.2 & 1.8 & 11.5 & 16.3 \\
\hline Egypt & 4.1 & 10.4 & 14.8 & 3.7 & 9.6 & 13.8 \\
\hline Eritrea & 2.3 & 10.7 & 16.9 & 3.5 & 9.3 & 15.5 \\
\hline Ethiopia & 5.0 & 9.6 & 14.9 & 3.3 & 10.9 & 13.9 \\
\hline Gabon & 2.2 & 14.6 & 22.6 & 1.0 & 13.8 & 18.0 \\
\hline Gambia & 4.0 & 13.8 & 20.0 & 6.0 & 13.3 & 16.7 \\
\hline Ghana & 0.9 & 6.8 & 16.0 & 1.8 & 7.6 & 13.8 \\
\hline Guinea & 3.4 & 9.5 & 18.7 & 2.8 & 10.3 & 14.5 \\
\hline Guinea-Bissau & 5.1 & 14.9 & 23.1 & 2.5 & 15.5 & 19.1 \\
\hline Kenya & 2.5 & 17.8 & 35.4 & 3.5 & 19.2 & 31.3 \\
\hline Lesotho & 1.5 & 11.2 & 16.3 & 0.9 & 12.6 & 17.0 \\
\hline Liberia & 6.0 & 14.2 & 21.5 & 2.5 & 14.6 & 24.3 \\
\hline Libya & 11.1 & 24.6 & 34.9 & 13.0 & 22.4 & 27.5 \\
\hline Madagascar & 0.7 & 13.7 & 20.0 & 1.7 & 12.1 & 16.0 \\
\hline Malawi & 3.6 & 15.3 & 18.5 & 3.4 & 10.0 & 15.0 \\
\hline Mali & 2.4 & 13.2 & 24.4 & 2.7 & 12.0 & 23.8 \\
\hline Mauritania & 6.1 & 12.4 & 14.6 & 2.8 & 12.4 & 17.2 \\
\hline Mauritius & 7.7 & 14.7 & 26.7 & 4.1 & 15.5 & 24.4 \\
\hline Morocco & 2.0 & 8.2 & 17.2 & 2.3 & 7.3 & 12.6 \\
\hline Mozambique & 1.6 & 9.3 & 14.0 & 1.5 & 10.9 & 13.7 \\
\hline Namibia & 5.9 & 11.8 & 20.1 & 4.1 & 8.8 & 19.2 \\
\hline Niger & 3.1 & 9.3 & 15.0 & 3.1 & 8.8 & 13.8 \\
\hline Nigeria & 3.0 & 9.5 & 20.1 & 1.5 & 6.6 & 11.0 \\
\hline Rwanda & 5.8 & 11.7 & 18.5 & 5.2 & 11.7 & 17.7 \\
\hline Sao Tome and Principe & 1.1 & 12.6 & 16.2 & 0.9 & 10.9 & 19.9 \\
\hline Senegal & 0.2 & 8.9 & 12.2 & 1.0 & 8.8 & 12.8 \\
\hline Seychelles & 4.0 & 11.8 & 17.4 & 2.3 & 10.9 & 15.2 \\
\hline Sierra Leone & 9.9 & 19.6 & 32.6 & 10.4 & 18.6 & 31.4 \\
\hline Somalia & 2.8 & 8.7 & 12.6 & 2.2 & 8.8 & 13.3 \\
\hline South Africa & 3.8 & 11.7 & 17.8 & 3.0 & 9.1 & 13.5 \\
\hline Sudan and South Sudan & 2.1 & 9.8 & 16.0 & 1.7 & 9.6 & 15.3 \\
\hline Swaziland & 2.7 & 8.0 & 13.9 & 2.5 & 9.4 & 13.4 \\
\hline
\end{tabular}


Table 3 continued

\begin{tabular}{|c|c|c|c|c|c|c|}
\hline \multirow[t]{2}{*}{ Country } & \multicolumn{3}{|c|}{ Relative error in the first formula (\%) } & \multicolumn{3}{|c|}{ Relative error in the second formula (\%) } \\
\hline & Minimum & Mean & Maximum & Minimum & Mean & Maximum \\
\hline Togo & 0.4 & 11.3 & 17.7 & 2.4 & 11.4 & 16.2 \\
\hline Tunisia & 7.0 & 13.9 & 24.4 & 1.8 & 14.6 & 21.1 \\
\hline Uganda & 0.7 & 13.7 & 26.1 & 1.7 & 14.3 & 17.9 \\
\hline United Republic of Tanzania & 5.2 & 12.0 & 25.0 & 2.8 & 9.9 & 23.2 \\
\hline Zambia & 2.4 & 17.2 & 24.4 & 2.7 & 12.2 & 23.5 \\
\hline Zimbabwe & 4.0 & 12.9 & 14.6 & 3.9 & 12.0 & 17.2 \\
\hline
\end{tabular}

From 1977 to 1982 , value of pressurized irrigation has been increased therefore; a minor decreasing is observable for area waterlogged. However, value of area salinized has been increased due to increase of agricultural water withdrawal and consequently a part of it that is used for irrigation. From 1982 to 1987, localized irrigation has been increased (Pollok et al. 1990) hence; value of area waterlogged has been diminished. Also, percentage of area equipped for irrigation salinized has been increased due to increase of agricultural water withdrawal again. From 1987 to 1992, pressurized irrigation and agricultural water withdrawal have been increased. Hence, percentage of area equipped for irrigation salinized has been increased and area waterlogged has been decreased. From 1992 to 1997 , values of surface irrigation (in comparison with pressurized irrigation), area waterlogged, agricultural water withdrawal, and percentage of area equipped for irrigation salinized, have been increased due to lack of appropriate management in the previous years and high costs as well as the dilemmas of these systems (Biswas 1986; Famoriyo 1984; Alam 1991). Note that NRI has been decreased from 1992 to 1997 and this indicates highlighted role of increase of surface irrigation (Houk et al. 2006). From 1997 to 2002, problems occurred in the previous period raised tendency to use of pressurized irrigation systems afresh but with a reasonable approach and competent management (Qadir and Oster 2004). This approach led to increase of pressurized irrigation as well as decrease of area waterlogged by irrigation. From 2002 to 2007, pressurized irrigation was still growing (Kigalu et al. 2008; Karlberg et al. 2007; Kheira 2009b) and values of area waterlogged by irrigation and percentage of area equipped for irrigation salinized were decreased due to suitable management and decrease of agricultural water withdrawal. From 2007 to 2011, we could see a fall in agricultural water withdrawal (however, this index is allowable to increase if a suitable use), percentage of area equipped for irrigation salinized, and area waterlogged and a growth in spate irrigation that needs to specific attention to deal with sedimentation (Embaye et al. 2012). The good event is raise of localized irrigation and its considerable impact on water conservation (Ward and Pulido-Velazquez 2008). However, value of conservation agriculture area is not desirable yet. In the final step, cropping intensity (area equipped) has been studied for Africa in the previous half of century.

\section{Cropping intensity (area equipped) for Africa in the previous half of century}

The Fig. 16 shows status of cropping intensity (area equipped) for Africa in the previous half of century.

In the first decade (1962-1972), we could not see a considerable change in cropping intensity. From 1972 to 1977, wheat and rice have been decreased significantly and instead vegetables, maize, flowers, and sugar beet, have been increased. From 1977 to 1982, wheat, rice, flowers, and fodder have been increased and instead maize, vegetables, and sugar beet have been decreased. From 1982 to 1987, vegetables have been increased and instead wheat, rice, and flowers have been decreased. In this period, irrigation systems were applied for soybeans, leguminous crops, tobacco, citrus, coffee, and rubber for the first time. From 1987 to 1992, rice, soybeans, tobacco, fodder, and leguminous crops have been decreased and instead wheat, maize, vegetables, flowers, coffee, and citrus have been decreased. In this period, irrigation systems were applied for barley, other cereals, groundnuts, sesame, sweet potatoes, cotton, grass and fodder, and tea, for the first time due to considerable increase of pressurized and spate irrigation (Fig. 15). From 1992 to 1997, wheat, barley, maize, and cotton have been increased and instead rice, vegetables, sweet potatoes, fodder, tea, sesame, groundnuts, sugar beet, leguminous crops, tobacco, citrus, coffee, other cereals, and grass and fodder have been decreased due to decrease of pressurized and spate irrigation systems (Fig. 15) that led to decrease of cropping intensity in Africa. In this period, irrigation systems were applied for millet and other roots and tubers for the first time. From 1997 to 2002, rice, barley, vegetables, soybeans, sugar beet, groundnuts, sesame, 
Table 4 General conditions of the countries for land use policy and agricultural water management based on Eqs. 15 and 16; the desirability more than $50 \%$ shows a suitable status, the desirability between 30 and $50 \%$ shows a fair status, and the desirability $<30 \%$ shows an unsuitable status for land use policy and agricultural water management (NA not available)

\begin{tabular}{|c|c|c|c|c|c|c|c|c|c|c|c|c|}
\hline Country & $I_{n 1}$ & $\mathrm{I}_{\mathrm{n} 2}$ & $\mathrm{I}_{\mathrm{n} 3}$ & $\mathrm{I}_{\mathrm{n} 4}$ & $\mathrm{I}_{\mathrm{n} 5}$ & $\mathrm{I}_{\mathrm{n} 6}$ & $100-I_{n 7}$ & $\mathrm{I}_{\mathrm{n} 8}$ & $\mathrm{I}_{\mathrm{n} 9}$ & $\mathrm{I}_{\mathrm{n} 10}$ & $\mathrm{I}_{\mathrm{avg} 1}$ & $\mathrm{I}_{\mathrm{avg} 2}$ \\
\hline Algeria & 13 & 37 & 23 & 88 & 9 & 12 & 75 & 1 & 46 & 6 & 31 & 23 \\
\hline Angola & 8 & 46 & 75 & 63 & 45 & 16 & 54 & 0 & 53 & 2 & 36 & 16 \\
\hline Benin & 13 & 65 & 47 & 54 & 38 & 56 & 26 & 0.02 & 29 & 1 & 33 & 10 \\
\hline Botswana & 1 & 43 & 45 & 79 & 17 & 4 & 64 & 0 & 43 & 1 & 30 & 4 \\
\hline Burkina Faso & 1 & 83 & 100 & 43 & 30 & 58 & 66 & 0 & 52 & 0.4 & 43 & 6 \\
\hline Burundi & 37 & 100 & 97 & 44 & 39 & 62 & 56 & 0 & 51 & 1 & 49 & 13 \\
\hline Cameroon & 22 & 46 & 50 & 61 & 67 & 34 & 37 & 0 & 54 & 0.3 & 37 & 9 \\
\hline Cape Verde & 7 & 43 & 18 & 73 & NA & 18 & 14 & 0 & NA & 7 & 23 & 31 \\
\hline Central African Republic & 5 & 68 & 68 & 44 & 52 & 100 & 44 & 0 & 51 & 0.01 & 43 & 0.3 \\
\hline Chad & 1 & 81 & 70 & 42 & 25 & 24 & 49 & 0 & 37 & 1 & 33 & 9 \\
\hline Comoros & 51 & 75 & 75 & 53 & 90 & 81 & 80 & 0 & 100 & 0.1 & 61 & 27 \\
\hline Congo & 13 & 42 & 34 & 66 & 65 & 6 & 50 & 0 & 63 & 0.04 & 34 & 2 \\
\hline Côte d'Ivoire & 74 & 55 & 40 & 54 & 47 & 43 & 29 & 0 & 36 & 1 & 38 & 13 \\
\hline Democratic Republic of the Congo & 12 & 72 & 62 & 38 & 62 & 80 & 56 & 0.1 & 65 & 0.1 & 45 & 5 \\
\hline Djibouti & 0 & 27 & 80 & 55 & 4 & 7 & 56 & 0 & 30 & 100 & 36 & 61 \\
\hline Egypt & 26 & 63 & 27 & 82 & 4 & 24 & 55 & 100 & 29 & 100 & 51 & 99 \\
\hline Equatorial Guinea & 43 & 67 & 69 & 69 & 96 & 6 & 57 & 0 & 87 & 0 & 49 & NA \\
\hline Eritrea & 0 & 88 & 80 & 44 & 13 & 25 & 62 & 0 & 39 & 1 & 35 & 12 \\
\hline Ethiopia & 9 & 93 & 83 & 49 & 42 & 81 & 69 & 0 & 62 & 3 & 49 & 30 \\
\hline Gabon & 42 & 15 & 27 & 85 & 72 & 7 & 56 & 0 & 71 & 1 & 38 & 5 \\
\hline Gambia & 1 & 46 & 82 & 54 & 24 & 33 & 83 & 0 & 61 & 1 & 39 & 21 \\
\hline Ghana & 45 & 54 & 59 & 69 & 44 & 45 & 32 & 0 & 37 & 0.5 & 38 & 11 \\
\hline Guinea & 24 & 72 & 86 & 44 & 64 & 39 & 21 & 1 & 42 & 1 & 39 & 13 \\
\hline Guinea-Bissau & 55 & 78 & 86 & 45 & 48 & 97 & 21 & 0 & 32 & 2 & 47 & 22 \\
\hline Kenya & 13 & 87 & 76 & 64 & 35 & 50 & 71 & 1 & 59 & 2 & 46 & 19 \\
\hline Lesotho & 2 & 81 & 42 & 57 & 29 & 14 & 68 & 0 & 53 & 1 & 35 & 10 \\
\hline Liberia & 35 & 58 & 67 & 48 & 95 & 93 & 45 & 0 & 78 & 0.02 & 52 & 2 \\
\hline Libya & 20 & 25 & 3 & 95 & 6 & 3 & 56 & 0.5 & 31 & 22 & 26 & 27 \\
\hline Madagascar & 18 & 78 & 76 & 60 & 61 & 51 & 45 & 0 & 56 & 31 & 47 & 52 \\
\hline Malawi & 4 & 90 & 85 & 52 & 44 & 53 & 55 & 0 & 54 & 2 & 44 & 22 \\
\hline Mali & 2 & 71 & 81 & 43 & 23 & 64 & 34 & 0 & 25 & 2 & 35 & 15 \\
\hline Mauritania & 3 & 66 & 55 & 58 & 7 & 29 & 12 & 3 & 0 & 11 & 24 & 32 \\
\hline Mauritius & 6 & 65 & 9 & 91 & NA & 6 & 61 & 0 & NA & 23 & 33 & 40 \\
\hline Morocco & 16 & 46 & 27 & 73 & 11 & 26 & 57 & 9 & 35 & 16 & 32 & 27 \\
\hline Mozambique & 5 & 68 & 87 & 41 & 39 & 56 & 62 & 0 & 56 & 3 & 42 & 23 \\
\hline Namibia & 1 & 69 & 36 & 75 & 13 & 13 & 40 & 0.3 & 24 & 1 & 27 & 7 \\
\hline Niger & 0 & 93 & 90 & 38 & 12 & 70 & 8 & 0 & 0.2 & 0.1 & 31 & 1 \\
\hline Nigeria & 10 & 56 & 26 & 58 & 51 & 54 & 66 & 0 & 65 & 1 & 39 & 11 \\
\hline Rwanda & 21 & 91 & 97 & 54 & 41 & 56 & 57 & 0 & 53 & 0.3 & 47 & 9 \\
\hline Sao Tome and Principe & 100 & 42 & 62 & 65 & NA & 28 & 57 & 0 & NA & 24 & 47 & 43 \\
\hline Senegal & 2 & 64 & 76 & 58 & 23 & 26 & 0 & 2 & 1 & 3 & 26 & 16 \\
\hline Seychelles & 81 & 49 & 80 & 100 & NA & 3 & 83 & 1 & NA & 9 & 51 & 43 \\
\hline Sierra Leone & 13 & 69 & 65 & 45 & 100 & 78 & 45 & 0 & 81 & 0.2 & 50 & 25 \\
\hline Somalia & 3 & 70 & 71 & NA & 16 & & 51 & 0 & 34 & 5 & 31 & 28 \\
\hline South Africa & 4 & 42 & 7 & 78 & 22 & 4 & 59 & 0.5 & 42 & 13 & 27 & 27 \\
\hline Sudan and South Sudan & 1 & 66 & 55 & 51 & 29 & 43 & 73 & 4 & 57 & 10 & 39 & 28 \\
\hline Swaziland & 10 & 88 & 31 & 67 & 25 & 14 & 60 & 0 & 46 & 26 & 37 & 49 \\
\hline
\end{tabular}


Table 4 continued

\begin{tabular}{|c|c|c|c|c|c|c|c|c|c|c|c|c|}
\hline Country & $\mathrm{I}_{\mathrm{n} 1}$ & $\mathrm{I}_{\mathrm{n} 2}$ & $\mathrm{I}_{\mathrm{n} 3}$ & $\mathrm{I}_{\mathrm{n} 4}$ & $I_{n 5}$ & $\mathrm{I}_{\mathrm{n} 6}$ & $100-I_{n 7}$ & $\mathrm{I}_{\mathrm{n} 8}$ & $\mathrm{I}_{\mathrm{n} 9}$ & $I_{n 10}$ & $I_{\text {avg1 }}$ & $I_{\text {avg2 }}$ \\
\hline Togo & 9 & 63 & 57 & 57 & 42 & 56 & 21 & 0 & 28 & 0.1 & 33 & 3 \\
\hline Tunisia & 56 & 36 & 22 & 88 & 13 & 15 & 68 & 5 & 44 & 8 & 35 & 27 \\
\hline Uganda & 30 & 97 & 81 & 57 & 53 & 41 & 73 & 0 & 72 & 0.1 & 50 & 6 \\
\hline United Republic of Tanzania & 16 & 82 & 82 & 59 & 44 & 49 & 62 & 0 & 58 & 2 & 45 & 15 \\
\hline Zambia & 1 & 72 & 68 & 56 & 42 & 34 & 35 & 0 & 38 & 2 & 35 & 17 \\
\hline Zimbabwe & 3 & 69 & 60 & 49 & 28 & 27 & 65 & 0 & 51 & 5 & 36 & 27 \\
\hline
\end{tabular}

Fig. 14 Variations of the main indices for Africa in the previous half of century, the left axis belongs to NRI, irrigation water requirement, and difference between NRI and irrigation water requirement and the right axis belongs to permanent crops to cultivated area, rural population to total population, total economically active population in agriculture to total economically active population, HDI, value added to GDP by agriculture, percentage of total cultivated area drained, and area equipped for irrigation to cultivated area (value of the HDI is not available before 1982 and values of irrigation water requirement and difference between NRI and irrigation water requirement are not available before 1997)

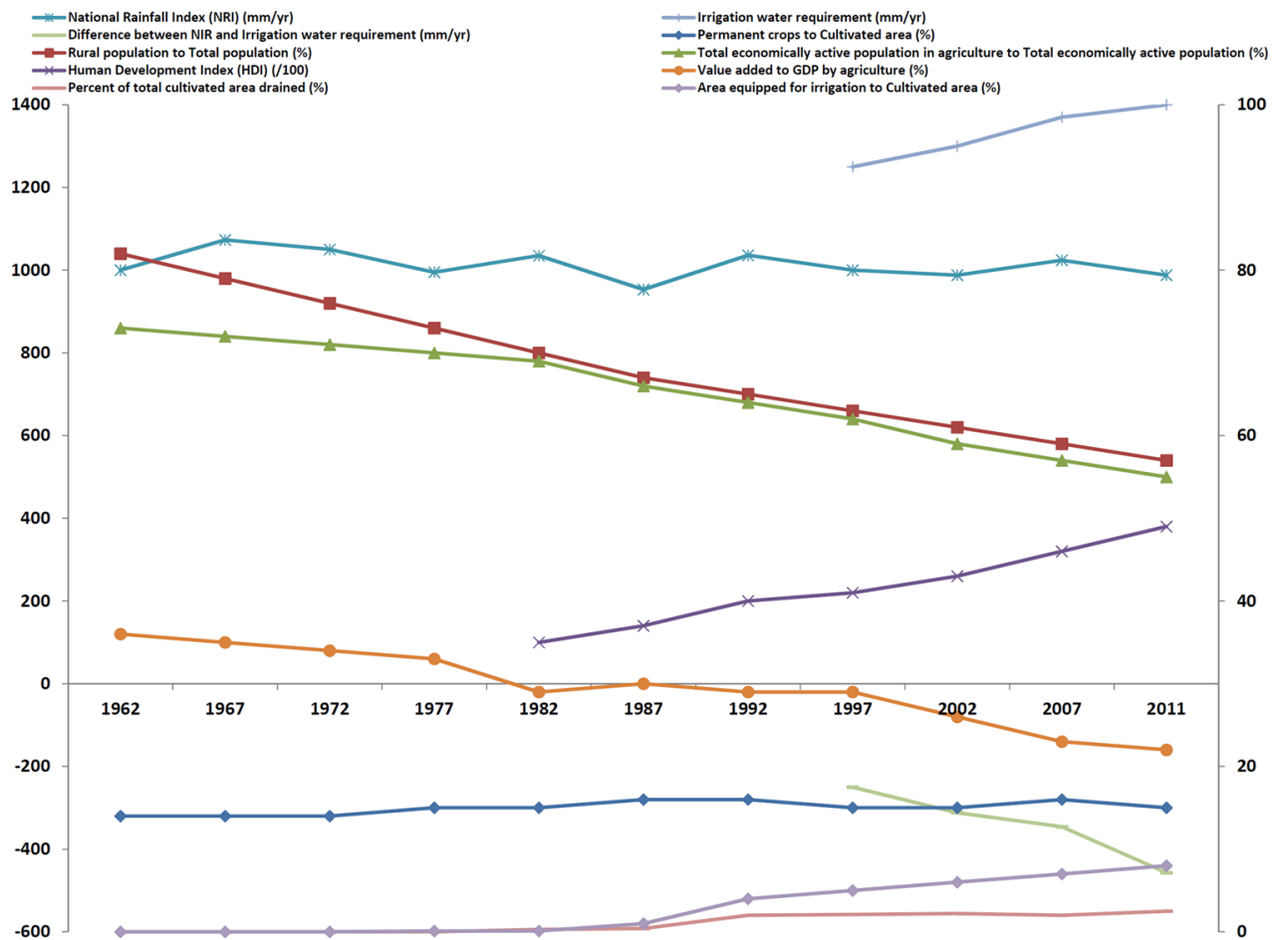

sweet potatoes, leguminous crops, rubber, coffee, tea, grapes, citrus, plantains, other cereals, and tobacco have been increased and instead wheat, maize, cotton, flowers millet, and other roots and tubers have been decrease. In this period, irrigation systems were applied for sunflower, potatoes, cassava, sugarcane, cocoa beans, oil palm, coconuts, and other fruits for the first time (increase of cropping intensity). From 2002 to 2007, wheat, barley, soybeans, sugarcane, oil palm, coconuts, grapes, cocoa beans, tea and other roots and tubers have been increased and instead rice, maize, sesame, vegetables, cassava, sugar beet, cotton, fodder, citrus, flowers, millet, groundnuts, sunflower, leguminous crops, plantains, coffee, other fruits, and other cereals have been decreased. From 2007 to 2011, wheat, rice, soybeans, sunflower, leguminous crops, fodder, cotton, and citrus have been increased and instead other crops have been decreased. Although a part of cropping intensity is depend to climate conditions (Lobell et al. 2008, 2011) and crop rotation (Tilman et al. 2002), but try and error policy (whether by governments or by farmers) leads to decrease of water use efficiency (WUE) and loss of water resources. For example, from 1997 to 2002 irrigation systems were applied for other fruits for the first time, whereas they were excluded from cropping intensity (area equipped) in the next periods (Fig. 16). As the other example, irrigation systems were applied for oil palm for the first time from 1997 to 2002 (3\%), but it suddenly was increased to $10 \%$ and afterward it was excluded from cropping intensity (area equipped) again (Fig. 16). Note that values of water use, per kilogram output and energy value are $2 \mathrm{~m}^{3} /$ $\mathrm{kg}$ and $0.73 \mathrm{~m}^{3} / 1,000 \mathrm{kcal}$, respectively, for oil palm. While, these values are $1.5 \mathrm{~m}^{3} / \mathrm{kg}$ and $0.47 \mathrm{~m}^{3} / 1,000 \mathrm{kcal}$ for cereals and $0.15 \mathrm{~m}^{3} / \mathrm{kg}$ and $0.49 \mathrm{~m}^{3} / 1,000$ for sugar beet (FAO 2011b). 


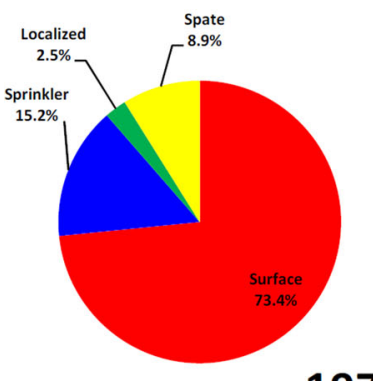

1977
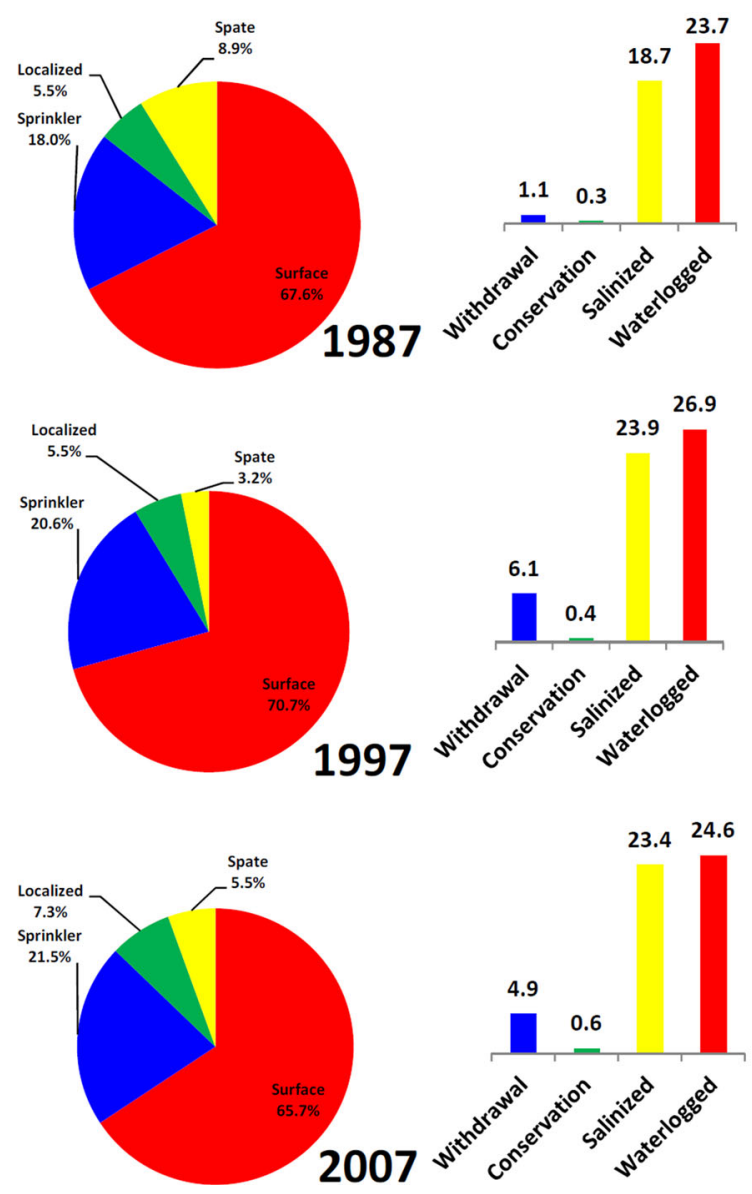

Fig. 15 Variations of the sub-main indices of land use policy and agricultural water management in Africa (value of the sub-main indices is not available before 1977), surface indicates value of surface irrigation to total irrigation, sprinkler indicates value of sprinkler irrigation to total irrigation, localized indicates value of localized irrigation to total irrigation, spate indicates value of spate

\section{Conclusion}

In this paper, land use policy and agricultural water management were analyzed in Africa within the past half of century. Number of 18 indices (as the main and sub-main indices) were selected to assess land use policy and agricultural water management based on their importance and other indices were not studied due to lack of adequate data.

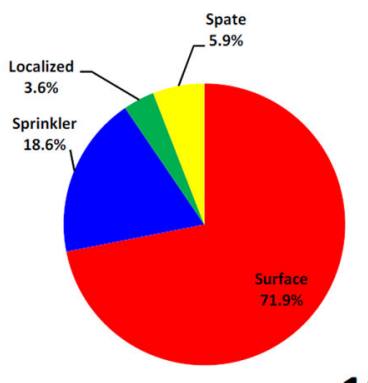

1982
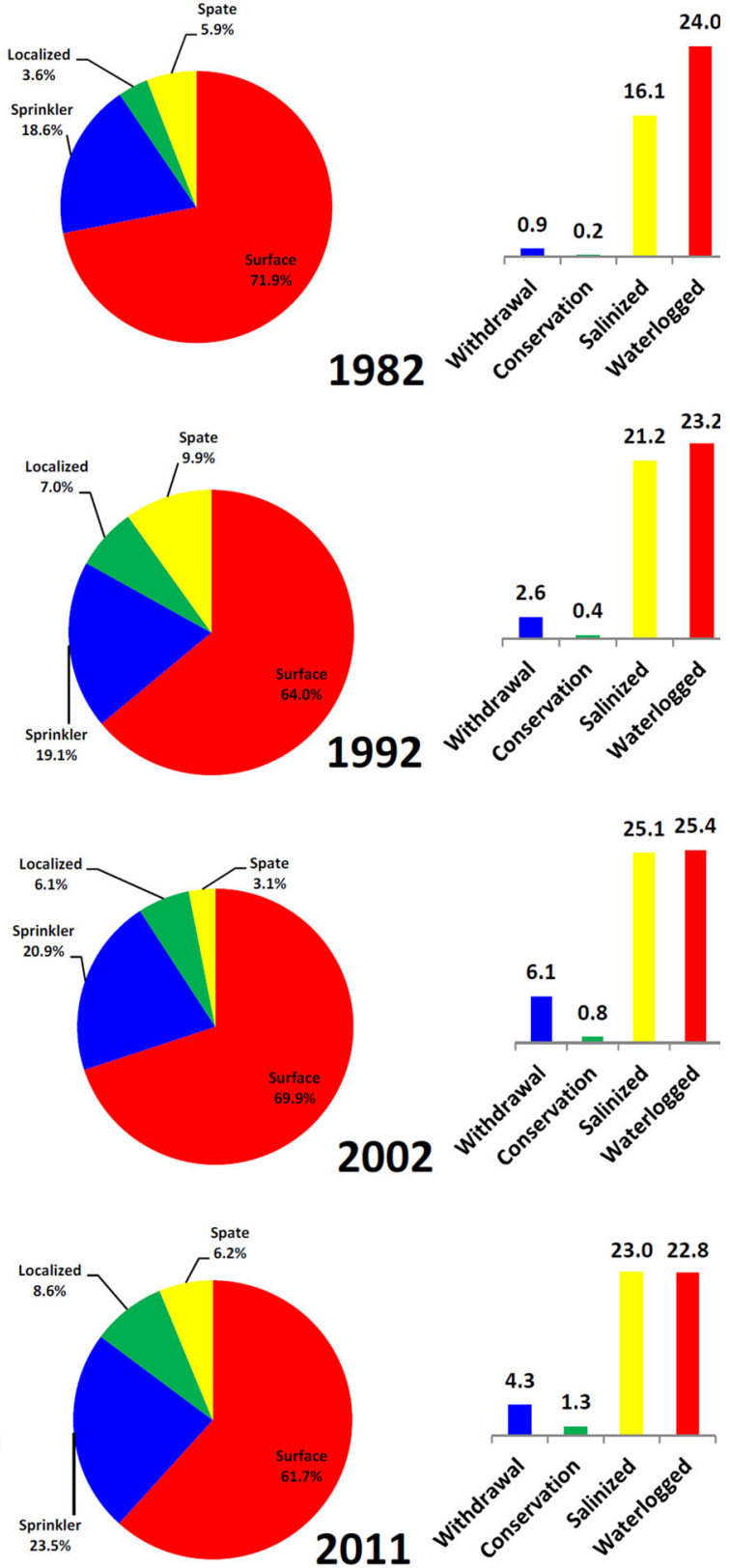

irrigation to total irrigation, withdrawal indicates agricultural water withdrawal $\left(10 \mathrm{~km}^{3} / \mathrm{year}\right)$, conservation indicates conservation agriculture area as percentage of cultivated area $(\%)$, salinized indicates percentage of area equipped for irrigation salinized (\%), waterlogged indicates area waterlogged by irrigation $(\%)$

The changes of the main indices in 2011 showed that they had similar values in some regions and had very different values in other regions due to nature of the indices and conditions of the countries. In the next step, the land use policy index was estimated using the other main indices. Using the obtained functions, not only the mentioned index in any year (with a relative error $<20 \%$ ) was estimated, but also the importance of each index for every region was 


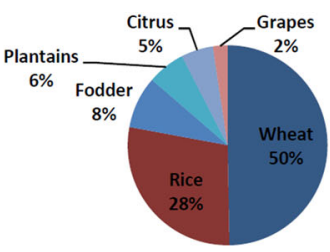

1962

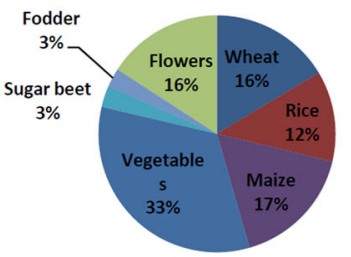

1977

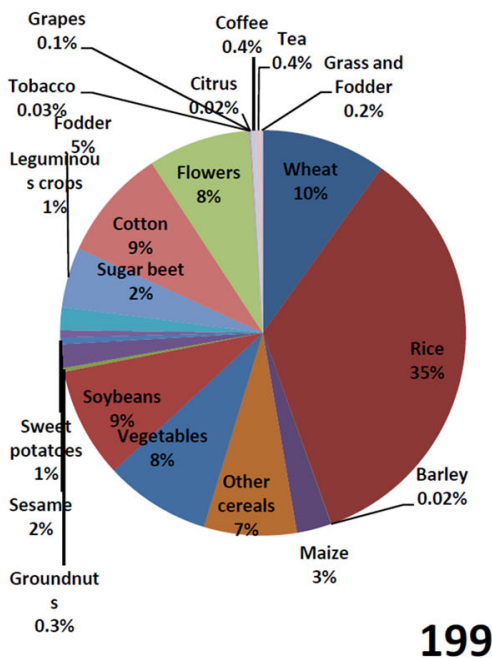

1992

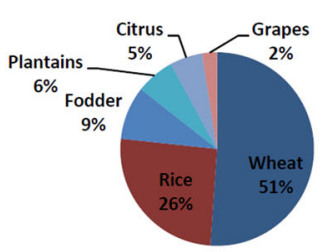

1967

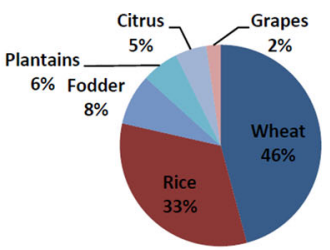

1972

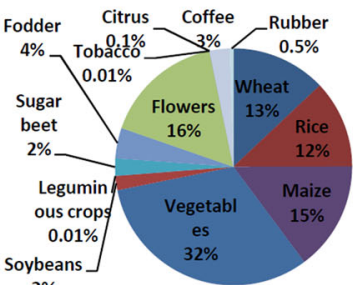

1982

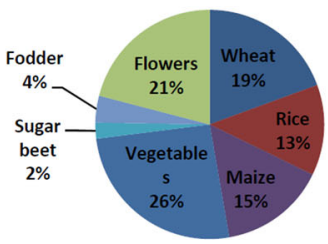

1987
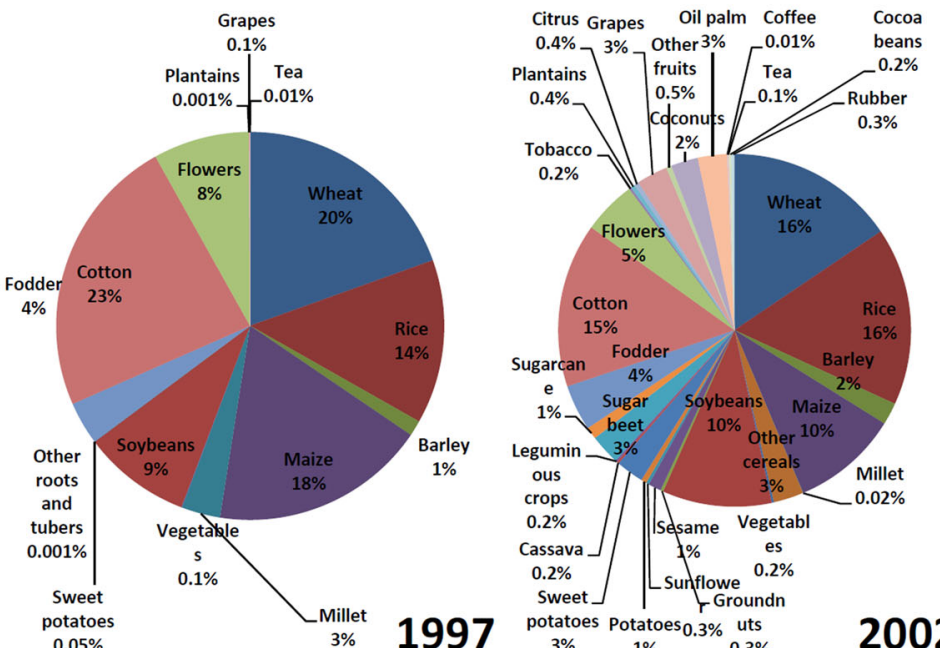

2002
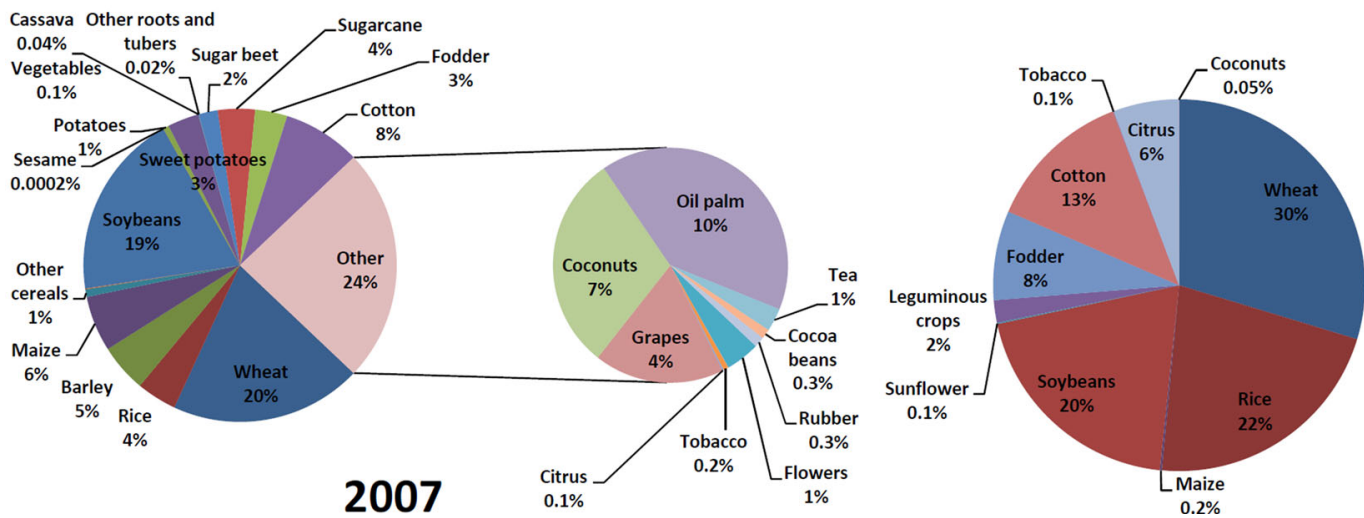

2011

Fig. 16 Status of cropping intensity (area equipped) for Africa in the previous half century

assessed. In addition, the amount of changes of the land use policy index for increase or decrease of each index in future years was predicted. The prioritization of the main indices showed that permanent crops to cultivated area, HDI, and value added to GDP by agriculture significantly affect the estimation of the land use policy index. The classification of the countries based on the main indices showed that Egypt had a better desirability of condition for land use policy and agricultural water management than the other countries. Evaluation of the trend of the main indices shows that increasing slope of land use policy index (due to decrease of rural development, labour force and value added to GDP by 
agriculture) was less than increasing slope of HDI and even water deficit (difference between NRI and irrigation water requirement) did not encourage governments and/or farmers for considerable increase in irrigation systems. Study of the sub-main indices showed that although status of pressurized irrigation was increasing, value of conservation agriculture area was not desirable. The results indicated that try and error policies should be avoided and expert comments be applied to the irrigation systems for any crop. The analysis of land use policy and agricultural water management for Africa in the past half of century provided a list of strengths and weaknesses. However, the only way to meet sustainable development is use of the past experiences to view bright horizons for future of land use policy and agricultural water management.

Open Access This article is distributed under the terms of the Creative Commons Attribution License which permits any use, distribution, and reproduction in any medium, provided the original author(s) and the source are credited.

\section{References}

Alam M (1991) Problems and potential of irrigated agriculture in Sub-Saharan Africa. J Irrig Drain Eng 117(2):155-172

Ale S, Bowling LC, Brouder SM, Frankenberger JR, Youssef MA (2009) Simulated effect of drainage water management operational strategy on hydrology and crop yield for Drummer soil in the Midwestern United States. Agric Water Manag 96(4):653-665

Ayars JE, Christen EW, Hornbuckle JW (2006) Controlled drainage for improved water management in arid regions irrigated agriculture. Agric Water Manag 86(1-2):128-139

Biswas AK (1986) Irrigation in Africa. Land Use Policy 3(4):269285

Burney JA, Naylor RL, Postel SL (2013) The case for distributed irrigation as a development priority in Sub-Saharan Africa. Proc Natl Acad Sci USA 110(31):12513-12517

Calder IR, Hall RL, Bastable HG, Gunston HM, Shela O, Chirwa A, Kafundu R (1995) The impact of land use change on water resources in Sub-Saharan Africa: a modelling study of Lake Malawi. J Hydrol 170(1):123-135

Drinkwater M (1989) Technical development and peasant impoverishment: land use policy in Zimbabwe's Midlands Province. J S Afr Stud 15(2):287-305

du Plessis HM (1985) Evapotranspiration of citrus as affected by soil water deficit and soil salinity. Irrig Sci 6(1):51-61

Embaye TG, Beevers L, Mehari Haile A (2012) Dealing with sedimentation issues in spate irrigation systems. Irrig Drain 61:220-230

Famoriyo S (1984) Land acquisition and irrigation in Nigeria. Land Use Policy 1(1):55-63

FAO (2011a) The state of the world's land and water resources for food and agriculture (SOLAW) - managing systems at risk. Food and Agriculture Organization of the United Nations. Rome and Earthscan, London

FAO (2011b) Climate change, water and food security. FAO water reports, Paper 36. ISSN 1020-1203

FAO (2012) The state of food and agriculture. ISSN 0081-4539

FAO (2013) AQUASTAT database. http://fao.org
Foley JA, DeFries R, Asner GP, Barford C, Bonan G, Carpenter SR, Snyder PK (2005) Global consequences of land use. Science 309(5734):570-574

Franks T, Garces-Restrepo C, Putuhena F (2008) Developing capacity for agricultural water management: current practice and future directions. Irrig Drain 57:255-267

Funnell DC (1994) Intervention and indigenous management: the geography of small-scale irrigation development in Morocco and Swaziland. Land Use Policy 11(1):45-54

Hanjra MA, Ferede T, Gutta DG (2009a) Pathways to breaking the poverty trap in Ethiopia: investments in agricultural water, education, and markets. Agric Water Manag 96(11):1596-1604

Hanjra MA, Ferede T, Gutta DG (2009b) Reducing poverty in SubSaharan Africa through investments in water and other priorities. Agric Water Manag 96(7):1062-1070

Hargreaves G, Hargreaves G, Riley J (1985) Irrigation water requirements for Senegal River Basin. J Irrig Drain Eng 111(3):265-275

Houk E, Frasier M, Schuck E (2006) The agricultural impacts of irrigation induced waterlogging and soil salinity in the Arkansas Basin. Agric Water Manag 85(1-2):175-183

Hussain I (2007) Pro-poor intervention strategies in irrigated agriculture in Asia: issues, lessons, options and guidelines. Irrig Drain 56:119-126

Hussain I, Turral H, Molden D, Ahmad M-ud-D (2007) Measuring and enhancing the value of agricultural water in irrigated river basins. Irrig Sci 25(3):263-282

Jury WA, Vaux HJ Jr (2007) The emerging global water crisis: managing scarcity and conflict between water users. Adv Agron 95:1-76

Karlberg L, Rockstrom J, Annandale JG, Steyn JM (2007) Low-cost drip irrigation - a suitable technology for southern Africa? An example with tomatoes using saline irrigation water. Agric Water Manag 89(1-2):59-70

Khan S, Hanjra MA, Mu J (2009) Water management and crop production for food security in China: a review. Agric Water Manag 96(3):349-360

Kheira AAA (2009a) Comparative assessment of new design criteria for irrigation improvement in Egypt. Water Resour Manag 23(11):2317-2342

Kheira AAA (2009b) Macromanagement of deficit-irrigated peanut with sprinkler irrigation. Agric Water Manag 96(10):1409-1420

Kigalu JM, Kimambo EI, Msite I, Gembe M (2008) Drip irrigation of tea (Camellia sinensis L.): 1 . Yield and crop water productivity responses to irrigation. Agric Water Manag 95(11):1253-1260

Kirpich P, Haman D, Styles S (1999) Problems of irrigation in developing countries. J Irrig Drain Eng 125(1):1-6

Kuper M, Bouarfa S, Errahj M, Faysse N, Hammani A, Hartani T, Marlet S, Zairi A, Bahri A, Debbarh A, Garin P, Jamin J-Y, Vincent B (2009) A crop needs more than a drop: towards a new praxis in irrigation management in North Africa. Irrig Drain 58:S231-S239

Lankford BA (2004) Resource-centred thinking in river basins; should we revoke the crop water requirement approach to irrigation planning? Agric Water Manag 68(1):33-46

Lobell DB, Burke MB, Tebaldi C, Mastrandrea MD, Falcon WP, Naylor RL (2008) Prioritizing climate change adaptation needs for food security in 2030. Science 319(5863):607-610

Lobell DB, Schlenker W, Costa-Roberts J (2011) Climate trends and global crop production since 1980. Science 333(6042):616-620

Mati BM (2011) Optimizing agricultural water management for the green revolution in Africa. Innovations as key to the green revolution in Africa. Springer, Heidelberg, 83-94. ISBN 978-90481-2541-8

Michaels PJ (1990) The greenhouse effect and global change: review and reappraisal. Int J Environ Stud 36(1-2):55-71 
Montenegro SG, Montenegro A, Ragab R (2010) Improving agricultural water management in the semi-arid region of Brazil: experimental and modelling study. Irrig Sci 28(4):301-316

Muzik I (2002) A first-order analysis of the climate change effect on flood frequencies in a subalpine watershed by means of a hydrological rainfall—runoff model. J Hydrol 267(1-2):65-73

Namara R, Munir E, Hanjra A, Castillo GE, Ravnborg HM, Smith L, Van Koppen B (2010) Agricultural water management and poverty linkages. Agric Water Manag 97(4):520-527

Norman WR (1998) Changes in land tenure and use during thirty years of small irrigation system operation. Irrig Drain Syst 12(2):161-184

Ogilvie A, Mahe G, Ward J, Serpantie G, Lemoalle J, Morand P, Barbier B, Diop AT, Caron A, Namarra R, Kaczan D, Lukasiewicz A, Paturel J-E, Liénou G, Clanet JC (2010) Water, agriculture and poverty in the Niger River basin. Water Int 35(5):594-622

Ozan LA, Alsharif KA (2013) The effectiveness of water irrigation policies for residential turfgrass. Land Use Policy 31:378-384

Pfister S, Bayer P, Koehler A, Hellweg S (2011) Projected water consumption in future global agriculture: scenarios and related impacts. Sci Total Environ 409(20):4206-4216

Pollok JG, Geldard GW, Sweet CPM (1990) Experience with approximately 600 hectare of drip irrigation at Simunye sugar estate. Swazil Agric Water Manag 17(1-3):151-158

Qadir M, Oster JD (2004) Crop and irrigation management strategies for saline-sodic soils and waters aimed at environmentally sustainable agriculture. Sci Total Environ 323(1-3):1-19

Qadir M, Sharma BR, Bruggeman A, Choukr-Allah R, Karajeh F (2007) Non-conventional water resources and opportunities for water augmentation to achieve food security in water scarce countries. Agric Water Manag 87(1):2-22

Sauerborn P, Klein A, Botschek J, Skowronek A (1999) Future rainfall erosivity derived from large-scale climate models-methods and scenarios for a humid region. Geoderma 93(3-4):269-276

Schultz B, De Wrachien D (2002) Irrigation and drainage systems research and development in the 21 st century. Irrig Drain 51:311-327

Steiner R, Keller A (1992) Irrigation land management model. J Irrig Drain Eng 118(6):928-942

Tilman D, Cassman KG, Matson PA, Naylor R, Polasky S (2002) Agricultural sustainability and intensive production practices. Nature 418:671-677

Traore Z, Fontane D (2007) Managing drought impacts: case study of Mali. Afr J Water Resour Plan Manage 133(4):300-308

Turunen M, Warsta L, Paasonen-Kivekas M, Nurminen J, Myllys M, Alakukku L, Aijo H, Puustinen M, Koivusalo H (2013) Modeling water balance and effects of different subsurface drainage methods on water outflow components in a clayey agricultural field in boreal conditions. Agric Water Manag 121:135-148

UNEP (2010) Africa water atlas. Division of early warning and assessment (DEWA). United Nations Environment Programme (UNEP). Nairobi, Kenya

Valero CS, Madramootoo CA, Stampfli N (2007) Water table management impacts on phosphorus loads in tile drainage. Agric Water Manag 89(1-2):71-80

Valipour M (2012) Critical areas of Iran for agriculture water management according to the annual rainfall. Eur J Sci Res 84:600-608. http://www.scopus.com/inward/record.url?eid=2s2.0-84865713214\&partnerID=MN8TOARS

Valipour M (2013a) Necessity of irrigated and rainfed agriculture in the world. Irrig Drain Sys Eng S9. doi:10.4172/2168-9768.S9-e001; http://www.omicsgroup.org/journals/2168-9768/pdfdownload.php ?download=2168-9768-S9-e001.pdf\&\&aid=12800
Valipour M (2013b) Evolution of irrigation-equipped areas as share of cultivated areas. Irrig Drain Sys Eng 2. doi:10.4172/2168-9768. 1000e114; http://www.omicsgroup.org/journals/2168-9768/pdf download.php?download=2168-9768-2-e114.pdf\&\&aid=12797

Valipour M (2013c) Need to update of irrigation and water resources information according to the progresses of agricultural knowledge. Agrotechnology. S10:e01. doi:10.4172/2168-9881.S10-e01; http://www.omicsgroup.org/journals/2168-9881/pdfdownload.php ?download=2168-9881-S10-e001.pdf\&\&aid=15774

Valipour M (2013d) Increasing irrigation efficiency by management strategies: cutback and surge irrigation. ARPN J Agric Biol Sci 8:35-43. http://www.arpnjournals.com/jabs/research_papers/rp_ 2013/jabs_0113_512.pdf

Valipour M (2014a) Drainage, waterlogging, and salinity. Arch Agron Soil Sci. doi:10.1080/03650340.2014.905676

Valipour M (2014b) Future of the area equipped for irrigation. Arch Agron Soil Sci. doi:10.1080/03650340.2014.905675

Valipour M (2014c) Importance of solar radiation, temperature, relative humidity, and wind speed for calculation of reference evapotranspiration. Arch Agron Soil Sci (Accepted)

Valipour M, Montazar AA (2012a) Optimize of all effective infiltration parameters in Furrow irrigation using visual basic and genetic algorithm programming. Aust J Basic Appl Sci 6:132-137. http://www.scopus.com/inward/record.url?eid=2-s2. 0-84867145182\&partnerID=MN8TOARS

Valipour M, Montazar AA (2012b) Sensitive analysis of optimized infiltration parameters in SWDC model. Adv Environ Biol 6:2574-2581. http://www.scopus.com/inward/record.url?eid=2s2.0-84875028847\&partnerID=MN8TOARS

Valipour M, Montazar AA (2012c) An evaluation of SWDC and WinSRFR models to optimize of infiltration parameters in furrow irrigation. Am J Sci Res 69:128-142. http://vali-pour. webs.com/4.pdf

Valipour M, Banihabib ME, Behbahani SMR (2012a) Parameters estimate of autoregressive moving average and autoregressive integrated moving average models and compare their ability for inflow forecasting. J Math Stat 8:330-338

Valipour M, Banihabib ME, Behbahani SMR (2012b) Monthly inflow forecasting using autoregressive artificial neural network. J Appl Sci 12:2139-2147

Valipour M, Banihabib ME, Behbahani SMR (2013) Comparison of the ARMA, ARIMA, and the autoregressive artificial neural network models in forecasting the monthly inflow of Dez dam reservoir. J Hydrol 476:433-441

Viala E (2008) Water for food, water for life a comprehensive assessment of water management in agriculture. Irrig Drain Syst 22(1):127-129

Ward FA, Pulido-Velazquez M (2008) Water conservation in irrigation can increase water use. Proc Natl Acad Sci USA 105(47):18215-18220

WBG (2013) WBG database. http://www.worldbank.org/

Weatherhead EK, Howden NJK (2009) The relationship between land use and surface water resources in the UK. Land Use Policy 26:S243-S250

Wheater H, Evans E (2009) Land use, water management and future flood risk. Land Use Policy 26:S251-S264

Wu IP, Barragan J, Bralts V (2013) Irrigation systems: water conservation. Encyclopedia of environmental management, Taylor \& Francis. doi:10.1081/E-EEM-120010068

Yang Y, Feng Z, Huang HQ, Lin Y (2008) Climate-induced changes in crop water balance during 1960-2001 in Northwest China. Agric Ecosyst Environ 127(1-2):107-118 